\title{
Organosulfates in atmospheric aerosols in Shanghai, China: seasonal and interannual variability, origin, and formation mechanisms
}

\author{
Yao Wang ${ }^{1}$, Yue Zhao ${ }^{1,2}$, Yuchen Wang ${ }^{3}$, Jian-Zhen Yu ${ }^{3,4}$, Jingyuan Shao ${ }^{5}$, Ping Liu ${ }^{1}$, Wenfei Zhu ${ }^{1}$, Zhen Cheng ${ }^{1}$, \\ Ziyue $\mathrm{Li}^{1}$, Naiqiang Yan $^{1,2}$, and Huayun Xiao ${ }^{1}$ \\ ${ }^{1}$ School of Environmental Science and Engineering, Shanghai Jiao Tong University, Shanghai 200240, China \\ ${ }^{2}$ Shanghai Institute of Pollution Control and Ecological Security, Shanghai 200092, China \\ ${ }^{3}$ Division of Environment \& Sustainability, Hong Kong University of Science \& Technology, Hong Kong SAR, China \\ ${ }^{4}$ Department of Chemistry, Hong Kong University of Science \& Technology, Hong Kong SAR, China \\ ${ }^{5}$ College of Flight Technology, Civil Aviation University of China, Tianjin 300300, China
}

Correspondence: Yue Zhao (yuezhao20@sjtu.edu.cn)

Received: 27 July 2020 - Discussion started: 14 September 2020

Revised: 22 January 2021 - Accepted: 25 January 2021 - Published: 26 February 2021

\begin{abstract}
Organosulfates (OSs) are ubiquitous in the atmosphere and serve as important tracers for secondary organic aerosols (SOAs). Despite intense research over the years, the abundance, origin, and formation mechanisms of OSs in ambient aerosols, particularly in regions with severe anthropogenic pollution, are still not well understood. In this study, we collected filter samples of ambient fine particulate matter ( $\mathrm{PM}_{2.5}$ ) over four seasons in both 2015-2016 and 2018-2019 at an urban site in Shanghai, China, and comprehensively characterized the OS species in these $\mathrm{PM}_{2.5}$ samples using an ultra-performance liquid chromatography quadrupole timeof-flight mass spectrometer equipped with an electrospray ionization (ESI) source (UPLC-ESI-QToFMS). Overall, we find that while the concentration of organic aerosols (OAs) decreased by $29 \%$ in 2018-2019 compared to that in 20152016, mainly as a result of the reduction of anthropogenic pollutant emissions in eastern China, the annually averaged concentrations of 35 quantified OSs were similar in both years $\left(65.5 \pm 77.5 \mathrm{ng} \mathrm{m}^{-3}, 0.57 \% \pm 0.56 \%\right.$ of OA in 2015 2016 vs. $59.4 \pm 79.7 \mathrm{ng} \mathrm{m}^{-3}, 0.66 \% \pm 0.56 \%$ of $\mathrm{OA}$ in 2018-2019), suggesting an increased contribution of SOAs to OAs in 2018-2019 compared to 2015-2016. Isoprene- and monoterpene-derived OSs were the two most abundant OS families, on average, accounting for $36.3 \%$ and $31.0 \%$ of the quantified OS concentrations, respectively, during both sampling years, suggesting an important contribution of biogenic emissions to the production of OSs and SOAs in Shanghai.
\end{abstract}

The abundance of biogenic OSs, particularly those arising from isoprene, exhibited strong seasonality (peaked in summer) but no significant interannual variability. In contrast, the quantified anthropogenic OSs had little seasonal variability and declined in 2018-2019 compared with those in 20152016. The $\mathrm{C}_{2}$ and $\mathrm{C}_{3}$ OS species that have both biogenic and anthropogenic origins contributed, on average, $19.0 \%$ of the quantified OSs, with $\mathrm{C}_{2} \mathrm{H}_{3} \mathrm{O}_{6} \mathrm{~S}^{-}, \mathrm{C}_{3} \mathrm{H}_{5} \mathrm{O}_{5} \mathrm{~S}^{-}$, and $\mathrm{C}_{3} \mathrm{H}_{5} \mathrm{O}_{6} \mathrm{~S}^{-}$being the most abundant species, together accounting for $76 \%$ of the $\mathrm{C}_{2}$ and $\mathrm{C}_{3}$ OS concentrations in 2015-2016 and 2018-2019. 2-Methyltetrol sulfate (2-MTS, $\mathrm{C}_{5} \mathrm{H}_{11} \mathrm{O}_{7} \mathrm{~S}^{-}$) and monoterpene-derived $\mathrm{C}_{10} \mathrm{H}_{16} \mathrm{NO}_{7} \mathrm{~S}^{-}$were the most abundant OSs and nitrooxy OSs in summer, on average, contributing $31 \%$ and $5 \%$ of the quantified OSs, respectively, during the summertime of the sampling years. The substantially larger concentration ratio of 2-MTS to 2methylglyceric acid sulfate (2-MAS, $\left.\mathrm{C}_{4} \mathrm{H}_{7} \mathrm{O}_{7} \mathrm{~S}^{-}\right)$in summer (6.8-7.8) compared to the other seasons (0.31-0.78) implies that low- $\mathrm{NO}_{x}$ oxidation pathways played a dominant role in isoprene-derived SOA formation in summer, while high$\mathrm{NO}_{x}$ reaction pathways were more important in other seasons. We further find that the production of OSs was largely controlled by the level of $\mathrm{O}_{x}\left(\mathrm{O}_{x}=\mathrm{O}_{3}+\mathrm{NO}_{2}\right)$, namely the photochemistry of OS precursors, particularly in summer, though sulfate concentration, aerosol acidity, and aerosol liquid water content (ALWC) that could affect the heterogeneous chemistry of reactive intermediates leading to OS for- 
mation also played a role. Our study provides valuable insights into the characteristics and mechanisms of OS formation in a typical Chinese megacity and implies that the mitigation of $\mathrm{O}_{x}$ pollution can effectively reduce the production of OSs and SOAs in eastern China.

\section{Introduction}

Secondary organic aerosols (SOAs) account for a significant fraction of atmospheric fine particulate matter $\left(\mathrm{PM}_{2.5}\right)$ (Jimenez et al., 2009; Huang et al., 2014) and contribute significantly to deteriorated air quality and Earth's climate forcing (Ramanathan et al., 2001; Mahowald, 2011; Shrivastava et al., 2017; Huang et al., 2014). SOAs consist of thousands of organic compounds that are diverse in molecular properties. Identification and quantification of the composition of SOAs are essential for understanding their composition, their chemistry of formation and evolution, their properties, and their climate and health impacts (Hoffmann et al., 2011; Nozière et al., 2015). However, currently only a small portion of organic matter in SOAs is identified as specific compounds (Hoffmann et al., 2011; Nozière et al., 2015; Johnston and Kerecman, 2019). Organosulfates (OSs) are important constituents of SOAs and have been frequently detected in both polluted and clean environments (Iinuma et al., 2007a; Surratt et al., 2008; Claeys et al., 2010; Froyd et al., 2010; Hawkins et al., 2010; Hatch et al., 2011; P. Lin et al., 2012; Stone et al., 2012; Hansen et al., 2014; He et al., 2014; Ma et al., 2014; Tao et al., 2014; Liao et al., 2015; Shakya and Peltier, 2015; Kourtchev et al., 2016; Meade et al., 2016; X. K. Wang et al., 2016; Hettiyadura et al., 2017; Huang et al., 2018; Le Breton et al., 2018; Wang et al., 2018; Hettiyadura et al., 2019; K. Wang et al., 2019; Brüggemann et al., 2020). It has been estimated that OSs account for $6 \%-$ $12 \%$ of total sulfur in a rural area in K-puszta, Hungary (Lukacs et al., 2009), $1.3 \%$ of fine particulate organic mass (FPOM) in Fairbanks, Alaska (Shakya and Peltier, 2013), and $1 \%-13 \%$ of FPOM across the continental United States (Tolocka and Turpin, 2012; Shakya and Peltier, 2015). Studies have also shown that OSs can affect aerosol properties such as acidity, viscosity, hygroscopicity, and light absorption (Nguyen et al., 2012; Hansen et al., 2015; Estillore et al., 2016; DeRieux et al., 2018; Fleming et al., 2019; Riva et al., 2019; Olson et al., 2019).

Chamber studies have revealed that OSs can originate from the (photo)oxidation of both biogenic precursors, such as isoprene (Gómez-González et al., 2008; Surratt et al., 2007b, a), monoterpenes (Iinuma et al., 2007a; Surratt et al., 2007a, 2008; Iinuma et al., 2007b, 2009), sesquiterpenes (Chan et al., 2011), and 2-methyl-3-buten-2-ol (Zhang et al., 2012), as well as anthropogenic precursors such as polycyclic aromatic hydrocarbons, long-chain alkanes, naphthenes (Riva et al., 2015, 2016b), and diesel and biodiesel fuel vapors (Blair et al., 2017) in the presence of sulfate aerosol or $\mathrm{SO}_{2}$. Many of the OSs observed in these chamber studies have also been detected in the ambient atmosphere, among which isoprene- and monoterpene-derived OSs are usually most abundant in forested, rural, and even urban areas (Stone et al., 2012; Ma et al., 2014; Meade et al., 2016; Hettiyadura et al., 2019; Kourtchev et al., 2016; Kristensen and Glasius, 2011; K. Wang et al., 2019; He et al., 2014; Hatch et al., 2011; Surratt et al., 2008; Hettiyadura et al., 2017).

In addition to the precursors, detailed formation mechanisms of OSs have been widely studied (Brüggemann et al., 2020). The acid-catalyzed ring-opening reaction of epoxides was established to be an important mechanism for the formation of OSs (Surratt et al., 2010; Y. H. Lin et al., 2012; Iinuma et al., 2009; Zhang et al., 2014), in particular for isoprene-derived OSs (Surratt et al., 2010; Y. H. Lin et al., 2012; Hatch et al., 2011). 2-Methyltetrol sulfate (2-MTS, $\mathrm{C}_{5} \mathrm{H}_{11} \mathrm{O}_{7} \mathrm{~S}^{-}$), formed via reactive uptake of isoprene epoxide (IEPOX) on sulfate, is one of the most abundant OSs in atmospheric aerosol (Chan et al., 2010; Liao et al., 2015) and can contribute up to $12.6 \%$ of the organic carbon mass in Atlanta, GA (Hettiyadura et al., 2019). Another OS formation pathway is the nucleophilic substitution of tertiary organonitrates by inorganic sulfate. Darer et al. (2011) found that tertiary organonitrates are thermodynamically unstable and can undergo nucleophilic substitution with sulfate to rapidly generate OSs. This mechanism can also explain the formation of some nitrooxy OSs (NOSs). In the atmospheric aqueous phase, sulfate radicals that can be produced by the oxidation of S(IV) species in the presence of transition metal ions (TMIs) (Grgic et al., 1998; Herrmann, 2003) or by the $\mathrm{OH}$ radical reaction with bisulfate (Herrmann, 2003; Jiang et al., 1992) can also react with unsaturated organic compounds to form OSs. Laboratory studies have shown that a large number of OSs were produced by the bulk aqueous-phase oxidation of aromatic compounds, isoprene, or the products of isoprene oxidation (methyl vinyl ketone (MVK) and methacrolein (MACR)) in the presence of inorganic sulfate or peroxodisulfate under irradiation (Nozière et al., 2010; Schindelka et al., 2013; Huang et al., 2020) or in the presence of S(IV) and TMIs under dark conditions (Huang et al., 2019). However, field observational evidence for this mechanism is still lacking. In addition, reactive uptake of $\mathrm{SO}_{2}$ on organic aerosol can result in the production of OSs. Laboratory studies have found that sulfur dioxide $\left(\mathrm{SO}_{2}\right)$ could react with the $\mathrm{C}=\mathrm{C}$ bond in unsaturated fatty acids under dark conditions to form OSs (Shang et al., 2016). Such OSs have been detected in the ambient atmosphere with an estimated contribution of $0.3 \% 0-0.9 \%$ to the organic mass (OM) in $\mathrm{PM}_{2.5}$ in southern China (Zhu et al., 2019). Recent studies have also shown efficient production of OSs from heterogeneous and aqueous-phase reactions of $\mathrm{SO}_{2}$ with organic peroxide-containing aerosols and SOAs (S. Y. Wang et al., 2019; Yao et al., 2019). Such OS production was found to be 
mainly a result of the direct reaction between $\mathrm{SO}_{2}$ and peroxides, rather than an acid-catalyzed reaction involving inorganic sulfate (S. Y. Wang et al., 2019). Currently, the acidcatalyzed ring-opening reaction of IEPOX has been the most well-studied mechanism and proved to be important in atmospheric OS formation by both field and modeling studies (Surratt et al., 2010; Kourtchev et al., 2016; Hettiyadura et al., 2019; Hatch et al., 2011; Chan et al., 2010; McNeill et al., 2012; Worton et al., 2013; He et al., 2018; Pye et al., 2013). However, the atmospheric importance of other OS formation mechanisms remains to be evaluated.

The aforementioned OS formation pathways can be affected by aerosol properties such as acidity, aerosol liquid water content (ALWC), and sulfate concentration. There is ample evidence from laboratory studies that increased aerosol acidity significantly enhances the production of OSs from acid-catalyzed reactions (Iinuma et al., 2007b; Chan et al., 2011; Surratt et al., 2007a, b; Zhang et al., 2012), while field studies have shown that the abundance of OSs was not or only weakly correlated with aerosol acidity in some locations (Nguyen et al., 2014; Budisulistiorini et al., 2015; Brüggemann et al., 2017; Rattanavaraha et al., 2016), suggesting the existence of other factors (e.g., ALWC, sulfate content) that control OS formation in these areas. ALWC has dual effects on OS formation. On one hand, elevated ALWC can reduce the viscosity and/or inhibit the liquid-liquid phase separation of aerosols, which would favor the dissolution and mixing of reactive intermediates such as IEPOX and multifunctional aldehydes in aqueous sulfate aerosols (Shiraiwa et al., 2011; Liao et al., 2015; McNeill et al., 2012) or $\mathrm{SO}_{2}$ in organic aerosols (Shang et al., 2016; Passananti et al., 2016; Yao et al., 2019), thereby enhancing OS formation. On the other hand, high ALWC would decrease aerosol acidity via dilution, hence inhibiting acid-catalyzed OS formation. High ALWC may also promote the hydrolysis of OSs in aqueous aerosols (Darer et al., 2011).

Quantification of OSs is important for understanding their abundance and the chemistry of formation and evolution in the atmosphere. Owing to the lack of authentic standards, the quantification of OSs remains a challenging task. Recently, several research groups have synthesized a series of authentic standards (e.g., glycolic acid sulfate, lactic acid sulfate, hydroxyacetone sulfate, 2-methyltetrol sulfate, benzyl sulfate, $\alpha$-pinene sulfate, $\beta$-pinene sulfate, and limonene sulfate) that are structurally the same as or similar to the OSs found in atmospheric aerosols (Kundu et al., 2013; Staudt et al., 2014; Hettiyadura et al., 2015; Wang et al., 2017; Olson et al., 2011; Huang et al., 2018; Budisulistiorini et al., 2015). They used these authentic standards to quantify OSs in ambient aerosols and provided important constraints on the abundance, origin, and chemistry of OSs in the atmosphere.

Currently, there are few studies characterizing atmospheric OSs in areas with severe anthropogenic pollution. Situated in the eastern Yangtze River Delta (YRD) of China, Shanghai has a population of more than 24 million and is plagued by air pollution (Behera et al., 2015; H. L. Wang et al., 2016). Here, we conducted a comprehensive investigation of the molecular composition, abundance, sources, and formation processes of OSs in ambient aerosols in Shanghai. More than 150 ambient $\mathrm{PM}_{2.5}$ samples collected over four seasons during both 2015-2016 and 2018-2019 in urban Shanghai were analyzed using an ultra-performance liquid chromatography quadrupole time-of-flight mass spectrometer equipped with an electrospray ionization (ESI) source (UPLC-ESIQToFMS) and 35 OSs were quantified using seven synthesized and commercially purchased OS standards. Seasonal and interannual variations of OSs, in response to the changes in emissions, meteorological conditions, and $\mathrm{PM}_{2.5}$ chemical compositions, were comprehensively characterized and the influencing factors such as aerosol acidity, ALWC, sulfate content, and oxidant level for OS formation were investigated. This study will help us understand the characteristics and mechanisms of OS and SOA production under the strong influence of anthropogenic pollution in Chinese megacities.

\section{Materials and methods}

\subsection{Ambient sample collection}

In total, 156 ambient $\mathrm{PM}_{2.5}$ samples were collected from 8 April 2015 to 16 January 2016 and from 23 October 2018 to 5 August 2019 in Shanghai, China. The sampling site is located on the rooftop of a $20 \mathrm{~m}$ tall teaching building on the Xuhui Campus of Shanghai Jiao Tong University at $31.201^{\circ} \mathrm{N}, 121.429^{\circ} \mathrm{E}$, which is downtown and surrounded by residential and commercial areas (see Fig. 1a, b). There is a main street $230 \mathrm{~m}$ east of the sampling site. The $\mathrm{PM}_{2.5}$ samples were collected on pre-baked $\left(550^{\circ} \mathrm{C}, 8 \mathrm{~h}\right)$ quartzfiber filters (Whatman) from 09:00 to 08:00 of the next day using a high-volume sampler (HiVol 3000, Ecotech) at a flow rate of $67.8 \mathrm{~m}^{3} \mathrm{~h}^{-1}$. The collected samples were wrapped in pre-baked $\left(550{ }^{\circ} \mathrm{C}, 8 \mathrm{~h}\right)$ aluminum foil and stored at $-20^{\circ} \mathrm{C}$ before analysis.

\subsection{Organosulfate measurements with UPLC-ESI-QToFMS}

An aliquot of $\sim 17 \mathrm{~cm}^{2}$ was removed from each filter sample and extracted in $3 \mathrm{~mL}$ of methanol (LC-MS grade, CNW Technologies $\mathrm{GmbH}$ ) twice under sonication in an ice bath at $4{ }^{\circ} \mathrm{C}$ for $30 \mathrm{~min}$. The extracts derived each time were combined and filtered through a $0.45 \mu \mathrm{m}$ polytetrafluoroethylene (PTFE) syringe filter (CNW Technologies $\mathrm{GmbH}$ ) to remove insoluble materials and subsequently concentrated to $250 \mu \mathrm{L}$ with a gentle stream of ultra-high-purity nitrogen (Shanghai Likang Gas Co., Ltd). The resulting extracts were mixed with ultrapure water (milliQ, $18.2 \mathrm{M} \Omega \mathrm{cm}$ ) of the same volume and centrifuged at $12000 \mathrm{rpm}$ and $4^{\circ} \mathrm{C}$ for $20 \mathrm{~min}$ using a centrifuge (Cence, TGL-16M) to get the supernatant for analysis. 


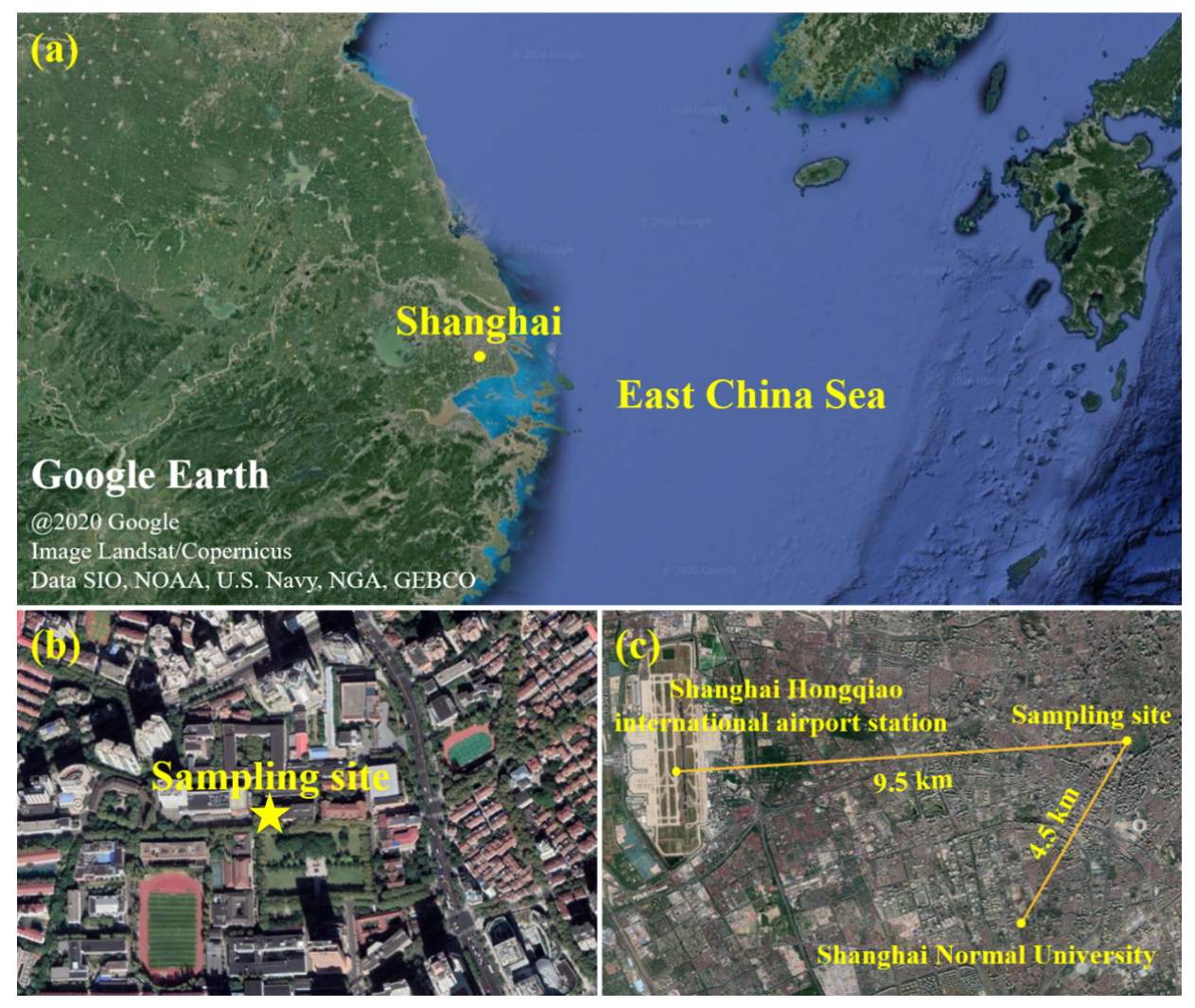

Figure 1. (a) Map of Shanghai. (b) Map of the sampling site on the Xuhui Campus of Shanghai Jiao Tong University in downtown Shanghai at $31.201^{\circ} \mathrm{N}, 121.429^{\circ}$ E. (c) Map of the $\mathrm{PM}_{2.5}$ sampling site, the meteorological station at Shanghai Hongqiao international airport, the air quality monitoring station at Shanghai Normal University, and the distances between them.

The resulting solutions were analyzed using an Acquity UPLC (Waters) coupled to a Xevo G2-XS QToFMS (Waters) having a mass resolving power of $\geq 40000$ and equipped with an ESI source. The analytes were separated by an ethylene-bridged hybrid (BEH) $\mathrm{C}_{18}$ column $(2.1 \times 100 \mathrm{~mm}, 1.7 \mu \mathrm{m}$ particle size, Waters $)$ at $50^{\circ} \mathrm{C}$. A gradient elution procedure was performed using water (A) and methanol (B), both containing $0.1 \%$ acetic acid $(v / v)$ as the eluents. A was maintained at $99 \%$ for $1.5 \mathrm{~min}$, decreased to $46 \%$ in $6.5 \mathrm{~min}$ and to $5 \%$ in $3 \mathrm{~min}$, then decreased to $1 \%$ in $1 \mathrm{~min}$ and, after being held for $2 \mathrm{~min}$, finally returned to $99 \%$ in $0.5 \mathrm{~min}$ and held for $1.5 \mathrm{~min}$ to equilibrate the column. The total eluent flow rate was $0.33 \mathrm{~mL} \mathrm{~min}^{-1}$ and the sample injection volume was $2.0 \mu \mathrm{L}$. The ESI source was operated in the negative ion mode under optimum conditions as follows: capillary voltage $2.0 \mathrm{kV}$, sampling cone voltage $40 \mathrm{~V}$, source offset voltage $80 \mathrm{~V}$, source temperature $115^{\circ} \mathrm{C}$, desolvation gas temperature $450^{\circ} \mathrm{C}$, cone gas flow $50 \mathrm{~L} \mathrm{~h}^{-1}$, and desolvation gas flow $900 \mathrm{~L} \mathrm{~h}^{-1}$.

The quantified OSs as well as the authentic and surrogate standards used for the quantification of each OS are listed in Table 1 . The OS standards were mainly selected by referring to Hettiyadura et al. (2019), which is based upon a comparison of the tandem mass spectrometry (MS/MS) pattern between authentic standards and targeted OSs in ambient aerosols, as well as to Wang et al. (2018). Glycolic acid sulfate (GAS, $\mathrm{C}_{2} \mathrm{H}_{3} \mathrm{O}_{6} \mathrm{~S}^{-}$) and lactic acid sulfate (LAS, $\mathrm{C}_{3} \mathrm{H}_{5} \mathrm{O}_{6} \mathrm{~S}^{-}$) were synthesized according to Olson et al. (2011). Because LAS and GAS are too small in molecular size, we could not find a promising stain to use thin layer chromatography (TLC) on silica gel to purify them. Instead, we employed ${ }^{1} \mathrm{H}$ NMR and an internal standard (dichloroacetic acid) to determine their purities (8\% for GAS and $15 \%$ for LAS). Limonaketone sulfate $\left(\mathrm{C}_{9} \mathrm{H}_{15} \mathrm{O}_{6} \mathrm{~S}^{-}\right)$and $\alpha$-pinene sulfate $\left(\mathrm{C}_{10} \mathrm{H}_{17} \mathrm{O}_{5} \mathrm{~S}^{-}\right)$were synthesized as described in Wang et al. (2017). Other OS standards including sodium methyl sulfate $\left(\mathrm{CH}_{3} \mathrm{O}_{4} \mathrm{~S}^{-}, 99 \%\right.$, Macklin), sodium octyl sulfate $\left(\mathrm{C}_{8} \mathrm{H}_{17} \mathrm{O}_{4} \mathrm{~S}^{-}, 95 \%\right.$, SigmaAldrich), and potassium phenyl sulfate $\left(\mathrm{C}_{6} \mathrm{H}_{5} \mathrm{O}_{4} \mathrm{~S}^{-}, 98 \%\right.$, Tokyo Chemical Industry, Shanghai) were commercially purchased. The MS/MS measurement of quantified OSs were also performed at a collision energy of $10-50 \mathrm{eV}$ to confirm whether they are OSs by the sulfur-containing fragment ions observed. In this study, most quantified OSs were fragmented to the bisulfate anion $(\mathrm{m} / \mathrm{z}, 97)$ and several quantified OSs were only fragmented to the sulfate radical anion $(m / z 96)$ and the sulfate radical anion $(m / z 80)$ (see Fig. S1 in the Supplement). 
Table 1. Organosulfates (in $\mathrm{ng} \mathrm{m}^{-3}$ ) quantified by UPLC-ESI-QToFMS.

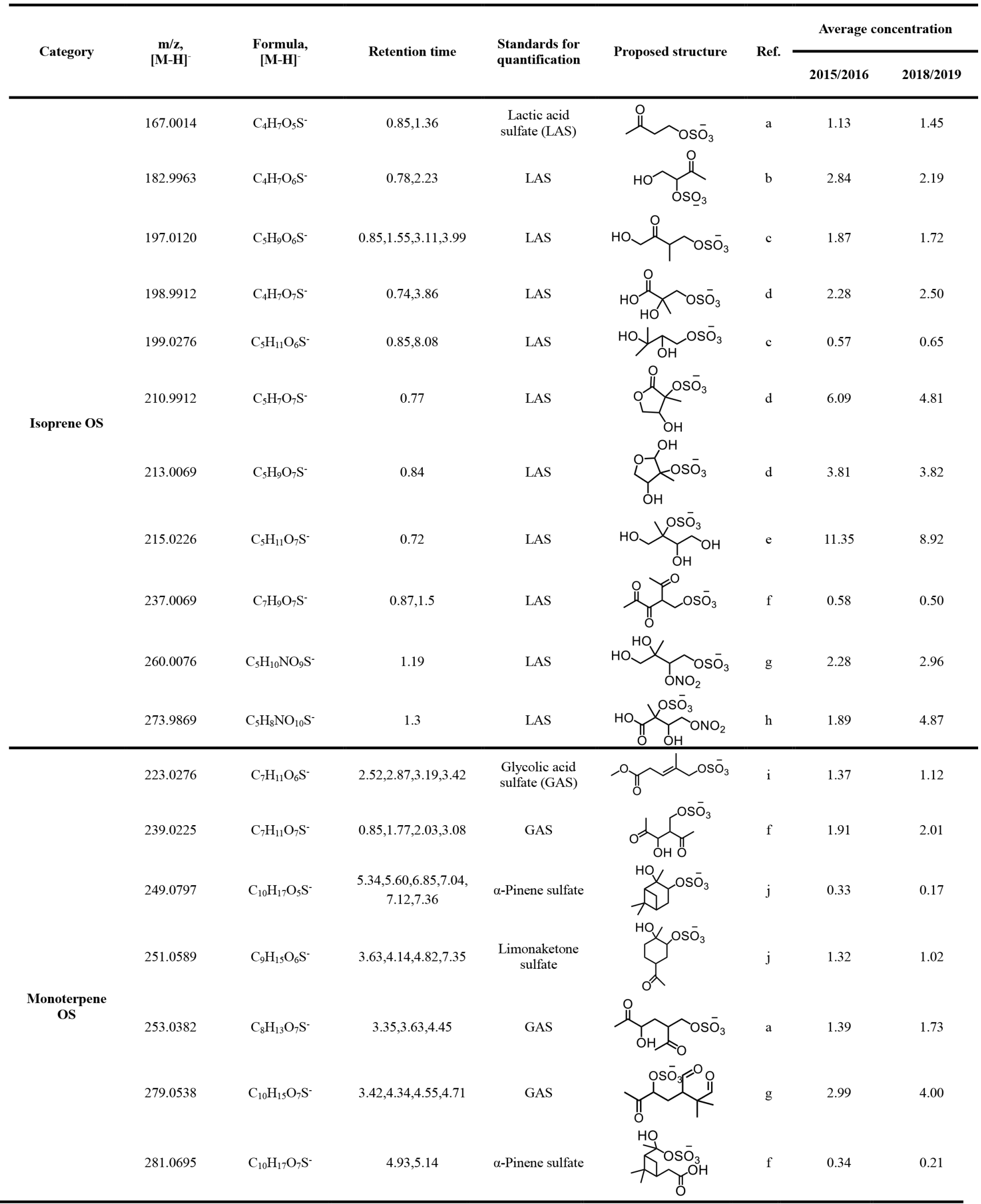


Table 1. Continued.

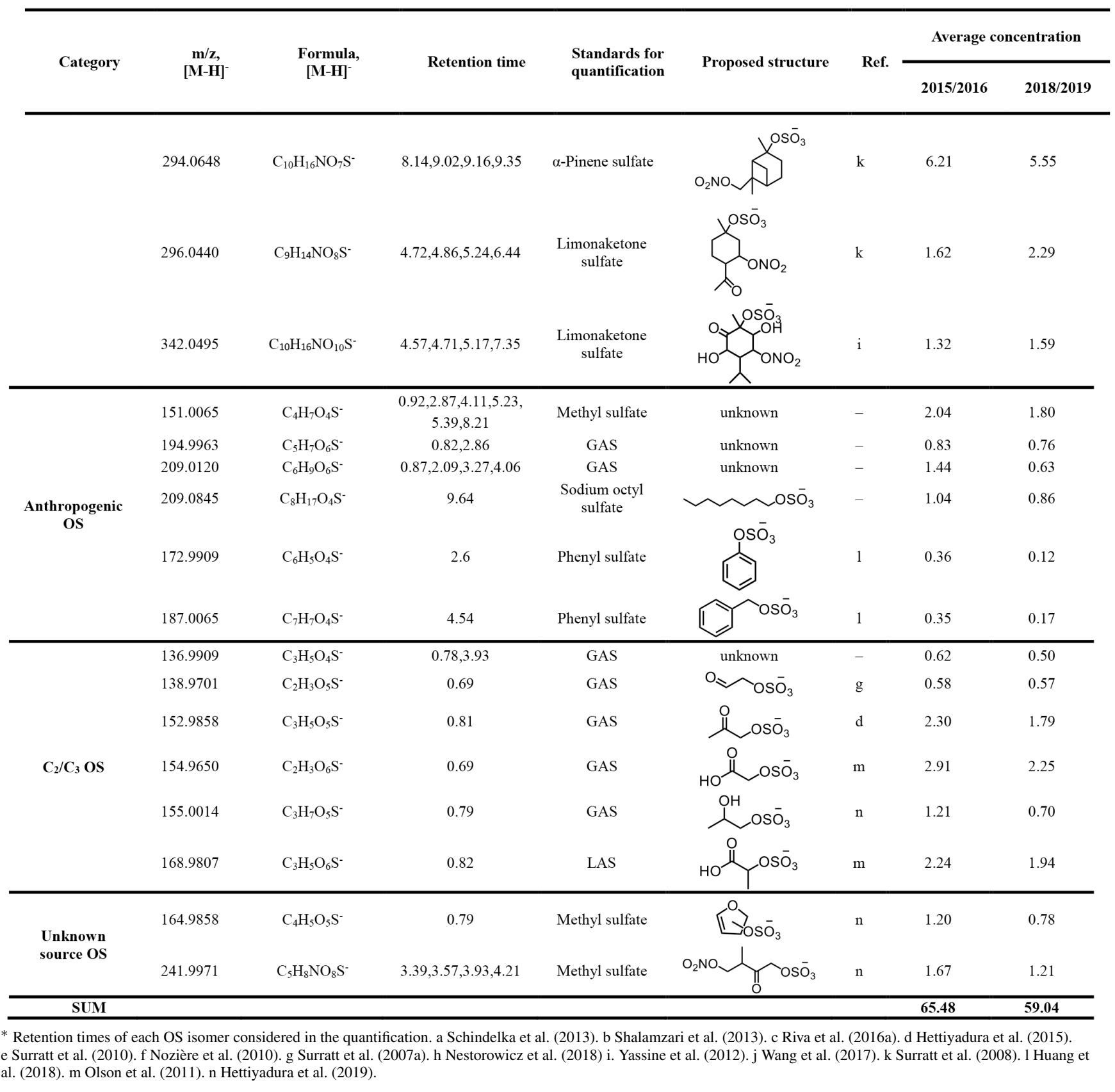

\subsection{Auxiliary measurements}

Meteorological parameters, including temperature, relative humidity (RH), and wind speed (WS), were continuously monitored by the Shanghai Hongqiao international airport station, which is $9 \mathrm{~km}$ west of the sampling site (Fig. 1c). The concentrations of $\mathrm{SO}_{2}$, nitrogen dioxide $\left(\mathrm{NO}_{2}\right), \mathrm{O}_{3}$, and $\mathrm{PM}_{2.5}$ were measured by a state-controlled air quality monitoring station on the Xuhui Campus of Shanghai Normal University, which is $4.5 \mathrm{~km}$ southwest of the sampling site for the $\mathrm{PM}_{2.5}$ filter samples (Fig. 1c). Organic carbon (OC) and elemental carbon (EC) in $\mathrm{PM}_{2.5}$ filter samples were measured by a thermal-optical multiwavelength carbon analyzer (DRI Model 2015). The concentration of OM was derived by multiplying the OC by 1.6 (Tao et al., 2017). Water-soluble inorganic compounds including sulfate, nitrate, chloride, ammonium, potassium, and calcium were determined with an ion chromatograph (Metrohm MIC). The seasonal and annual average values of meteorological parameters and concentrations of trace gases, $\mathrm{PM}_{2.5}$, and $\mathrm{PM}_{2.5}$ 's major compo- 
nents in 2015-2016 and 2018-2019 are listed in Table S1 in the Supplement.

\subsection{Estimation of aerosol liquid water content and $\mathrm{pH}$}

The ISORROPIA-II thermodynamic model (Fountoukis and Nenes, 2007) was employed to predict ALWC and aerosol $\mathrm{pH}$. The aerosol water-soluble inorganic ion concentrations, as well as temperature and $\mathrm{RH}$, were used as the model input. The model was run in the forward mode for metastable aerosols, which was shown to give a more accurate representation of aerosol $\mathrm{pH}$ than by using the reverse-mode calculations with only aerosol data input (Guo et al., 2015; Hennigan et al., 2015). ISORROPIA-II calculates the equilibrium concentration of aerosol hydronium ions $\left(\mathrm{H}_{\text {air }}^{+}\right)$per volume of air $\left(\mu \mathrm{g} \mathrm{m}^{-3}\right)$ along with ALWC $\left(\mu \mathrm{g} \mathrm{m}^{-3}\right)$. The aerosol $\mathrm{pH}$ was then derived by

$\mathrm{pH}=-\log _{10}\left(\mathrm{H}_{\mathrm{aq}}^{+}\right)=-\log _{10} \frac{1000 \mathrm{H}_{\mathrm{air}}^{+}}{\mathrm{ALWC}}$,

where $\mathrm{H}_{\mathrm{aq}}^{+}$is the concentration of hydronium ions in aqueous aerosol $\left(\mathrm{mol} \mathrm{L}^{-1}\right)$. In this study, ALWC associated with organic aerosols and its influences on aerosol $\mathrm{pH}$ were not considered. However, previous studies showed that water uptake by organic aerosol only contributed a minor fraction (5\%) to the total ALWC and had a negligible influence on aerosol pH in haze events in China (Liu et al., 2017). The seasonally and annually averaged ALWC and aerosol pH levels in 2015-2016 and 2018-2019 are also given in Table S1 in the Supplement.

\subsection{Quality control}

The extraction efficiency of OS species in filter samples was evaluated by measuring the recovery of 10 different OS standards (see Table S2 in the Supplement). The synthesized and commercially purchased OS standards were spiked into blank and pre-baked quartz filters then extracted and analyzed with the same procedures for the ambient samples. The recoveries of OS standards were about $84 \%-94 \%$ except for $\Delta$-carene OS, lactic acid sulfate, and glycolic acid sulfate, the recoveries of which were $66 \%, 72.5 \%$, and $77.8 \%$, respectively (see Table S2 in the Supplement). This result suggests a fairly high extraction efficiency for the majority of OS species in this study.

In addition, we evaluated the matrix effect on the signal response of OSs by comparing the measured signal intensity of OS standards added to the extracts of ambient $\mathrm{PM}_{2.5}$ filter samples with that of pure OS standard solutions. Table S3 in the Supplement gives the ratios of measured signal intensity of OS standards in filter sample extracts to those in pure solutions. As for the standards that were already present in the samples, we subtracted the response in the sample from the total (sample + standard) before calculating the ratio. Most of the OS standards had a ratio of around 1, suggesting no obvious matrix effect on the measurement of the majority of OS species. However, the two smallest OS standards, methyl sulfate and glycolic acid sulfate, which were the very first species eluted from the LC column, had a ratio significantly smaller than 1, suggesting the inhibited ionization of these two OSs likely by the highly soluble and polar species in the filter samples that were co-eluted with these two OSs. We note that the matrix effect for these two OSs is dependent on the $\mathrm{PM}_{2.5}$ mass loading. For example, the signal ratio of glycolic acid sulfate standard measured in filter sample extracts vs. pure solutions ranged from $0.17-0.31$ (Table S3, Exps. $1-2$ ) for very polluted days to $0.45-0.53$ for clean days (Table S3, Exps. 3-4). This implies that the abundance of glycolic acid sulfate in ambient aerosols reported here may be underestimated by a factor of $2-6$ due to the matrix effect.

\section{Results and discussion}

\subsection{Overview of pollution characteristics during sampling periods}

Figure 2 shows the time series of meteorological parameters $\mathrm{O}_{3}, \mathrm{NO}_{2}, \mathrm{SO}_{2}, \mathrm{PM}_{2.5}$, and $\mathrm{PM}_{2.5}$ 's major components as well as $\mathrm{H}_{\mathrm{aq}}^{+}$and ALWC during the sampling periods. The average values (concentrations) of each parameter (species) are given in Table S1 in the Supplement. Overall, the meteorological conditions (wind speed, temperature, and RH) were similar in 2015-2016 and 2018-2019. While the $\mathrm{NO}_{2}$ concentration decreased from $27.0 \pm 13.0 \mathrm{ppb}$ in 2015 2016 to $21.3 \pm 10.3 \mathrm{ppb}$ in $2018-2019$, the $\mathrm{O}_{3}$ level had no obvious difference between the two years $(29.8 \pm 15.2 \mathrm{ppb}$ in $2015-2016$ vs. $29.6 \pm 13.9$ ppb in 2018-2019), consistent with the nonlinear response of $\mathrm{O}_{3}$ production to precursor emissions (Liu and Wang, 2020). The annual average mass loading of $\mathrm{PM}_{2.5}$ declined by $34.5 \%$ in 2018 $2019\left(38.6 \pm 24.0 \mathrm{\mu g} \mathrm{m}^{-3}\right)$ compared to that in 2015-2016 $\left(59.0 \pm 37.9 \mathrm{\mu g} \mathrm{m}^{-3}\right)$, largely driven by the strong decrease in the abundance of OM $(29.1 \%)$ and sulfate $(37.4 \%)$. The decrease of $\mathrm{PM}_{2.5}$, OM, and sulfate concentrations from 20152016 to $2018-2019$ reflects a significant reduction in anthropogenic pollutant emissions in eastern China in recent years. In contrast to $\mathrm{OM}$ and sulfate, the concentration of nitrate showed little change between 2015-2016 $\left(8.8 \pm 8.9 \mu \mathrm{g} \mathrm{m}^{-3}\right)$ and 2018-2019 $\left(8.4 \pm 7.8 \mu \mathrm{g} \mathrm{m}^{-3}\right)$, despite an obvious decrease in $\mathrm{NO}_{2}$ concentration. This is at least partly a result of reduced aerosol acidity $\left(\mathrm{H}_{\mathrm{aq}}^{+}\right.$; see Fig. 2 and Table S1 in the Supplement) and thereby enhanced partitioning of $\mathrm{HNO}_{3}$ into the particle phase. Furthermore, the nitrate concentration showed a strong seasonality, ranging from $1.0 \pm 1.1$ and $3.4 \pm 3.2 \mu \mathrm{g} \mathrm{m}^{-3}$ in summer to $16.6 \pm 10.0$ and $14.1 \pm 10.0 \mathrm{\mu g} \mathrm{m}^{-3}$ in winter in 2015-2016 and 2018-2019, respectively, partly owing to the seasonal variation of temperature and aerosol acidity that modulates the gas-particle partitioning of nitrate (Fisseha et al., 2006; Guo et al., 2015; 
Griffith et al., 2015; Guo et al., 2016). A similar strong reduction in $\mathrm{PM}_{2.5}$ concentration and variations in aerosol composition over the past several years were observed in different regions in China (Tao et al., 2017; J. J. Wang et al., 2020; A. Ding et al., 2019; Wen et al., 2018). As a result of strong reductions in inorganic ion concentrations, ALWC decreased dramatically in $2018-2019\left(14.8 \pm 20.4 \mu \mathrm{g} \mathrm{m}^{-3}\right)$ compared to that in $2015-2016\left(24.4 \pm 27.0 \mu \mathrm{g} \mathrm{m}^{-3}\right)$. In short, anthropogenic pollutant emissions, as well as aerosol concentration and composition, varied significantly between 2015-2016 and 2018-2019 in Shanghai, which, as will be discussed below, has important implications for the production of OSs in ambient aerosols.

\subsection{Molecular composition of sulfur-containing organic compounds}

The organic compounds in ambient $\mathrm{PM}_{2.5}$ identified using UPLC-ESI-QToFMS were classified into four groups based on their elemental composition: $\mathrm{CHO}, \mathrm{CHON}, \mathrm{CHOS}$, and CHONS. Figure $3 \mathrm{a}$ and $\mathrm{b}$ show the average mass spectra of organic compounds in $\mathrm{PM}_{2.5}$ over a typical winter (2126 January 2019) and summer (23-28 July 2019) pollution episode. Overall, the sulfur-containing compounds were larger in molecular size than the $\mathrm{CHO}$ and $\mathrm{CHON}$ compounds, likely because of the addition of a sulfate group to the molecule. The molecular weight (MW) of most sulfurcontaining compounds was between 100-400 Da and for a few between 400-700 Da. The high-MW CHOS species (400-700 Da; see Table S4 in the Supplement) showed a larger contribution in winter than in summer, suggesting that they are more likely to arise from anthropogenic sources than biogenic emissions. Figure 3c shows the signal contribution of different compound categories as well as concentrations of sulfate, OM, and quantified OSs; Fig. 3d, e shows the number of identified organic compounds in each category during two pollution episodes. The CHOS compounds contributed most in terms of signal and number to the observed organic compounds in both winter and summer. The signal contributions and number of unquantified CHOS and CHONS did not vary significantly from winter to summer, whereas the signal contribution of quantified CHOS and CHONS species was significantly larger in summer than in winter (on average $15 \%$ vs. $7 \%$ for CHOS and $11 \%$ vs. $7 \%$ for CHONS). As will be discussed later, the abundance of quantified anthropogenic OSs was fairly constant across different seasons, in striking contrast to that of biogenic OSs, which showed strong seasonal variability. Therefore, a lack of seasonal variability for unquantified CHOS and CHONS implies that they may originate mainly from anthropogenic sources. In addition, both signal intensity and the number of $\mathrm{CHO}$ species increased significantly in summer, compared to those in winter. In contrast, CHON compounds contributed substantially more to the observed signals in winter than in summer (on average $25 \%$ vs. $7 \%$ ), though their numbers are quite similar dur- ing the two periods. This suggests an enhanced production and/or suppressed depletion of nitrogen-containing organic species in winter.

The CHOS compounds with an $\mathrm{O} / \mathrm{S}$ ratio of $\geq 4$ were assigned as potential OS species. Similarly, the CHONS compounds with an $\mathrm{O} /(\mathrm{N}+\mathrm{S})$ ratio of $\geq 7$ could be assigned as potential NOS species (P. Lin et al., 2012). $\mathrm{C}_{8} \mathrm{H}_{17} \mathrm{O}_{4} \mathrm{~S}^{-}$, $\mathrm{C}_{8} \mathrm{H}_{15} \mathrm{O}_{4} \mathrm{~S}^{-}$, and $\mathrm{C}_{5} \mathrm{H}_{11} \mathrm{O}_{4} \mathrm{~S}^{-}$were the highest OS peaks observed in the pollution episode in winter. The $\mathrm{C}_{8} \mathrm{H}_{17} \mathrm{O}_{4} \mathrm{~S}^{-}$ and $\mathrm{C}_{8} \mathrm{H}_{15} \mathrm{O}_{4} \mathrm{~S}^{-}$species may be derived from the photooxidation of diesel fuel vapors according to previous chamber studies (Blair et al., 2017). The $\mathrm{C}_{5} \mathrm{H}_{11} \mathrm{O}_{4} \mathrm{~S}^{-}$species was correlated well with $\mathrm{C}_{8} \mathrm{H}_{17} \mathrm{O}_{4} \mathrm{~S}^{-}$in 2015-2016 $(r=0.76)$ and 2018-2019 $(r=0.84)$, suggesting it may also be derived from diesel fuel vapors. The highest NOS peak in winter was $\mathrm{C}_{10} \mathrm{H}_{16} \mathrm{NO}_{7} \mathrm{~S}^{-}$, which likely originates from monoterpene oxidation (Surratt et al., 2008). $\mathrm{C}_{5} \mathrm{H}_{11} \mathrm{O}_{7} \mathrm{~S}^{-}, \mathrm{C}_{15} \mathrm{H}_{29} \mathrm{O}_{5} \mathrm{~S}^{-}$, and $\mathrm{C}_{13} \mathrm{H}_{25} \mathrm{O}_{5} \mathrm{~S}^{-}$were among the highest OS peaks observed in the summer pollution episode. $\mathrm{C}_{5} \mathrm{H}_{11} \mathrm{O}_{7} \mathrm{~S}^{-}$is an IEPOX-derived OS species (Surratt et al., 2010), while $\mathrm{C}_{15} \mathrm{H}_{29} \mathrm{O}_{5} \mathrm{~S}^{-}$and $\mathrm{C}_{13} \mathrm{H}_{25} \mathrm{O}_{5} \mathrm{~S}^{-}$may be derived from the oxidation of diesel fuel vapors (Blair et al., 2017). The highest NOS peak in summer was monoterpene-derived $\mathrm{C}_{10} \mathrm{H}_{16} \mathrm{NO}_{7} \mathrm{~S}^{-}$, the same as in winter.

\subsection{Quantified organosulfates}

In this study, we quantified 29 OS and six NOS compounds using a variety of authentic and surrogate OS standards (Table 1). The quantified OSs and NOSs accounted for $14 \%-$ $18 \%$ and $47 \%-67 \%$ by intensity of the identified CHOS and CHONS in polluted winter days and $15 \%-37 \%$ and $58 \%-$ $87 \%$ in polluted summer days (Fig. 3c), respectively. The increased contribution of the quantified OSs and NOSs in summer is because they are mainly derived from biogenic VOCs, which have greater emissions in summer than in other seasons (Guenther et al., 1995). We note that a large fraction of OS signals was not quantified owing to the lack of proper standards in this study. As discussed above, these unquantified OSs mainly originated from anthropogenic sources. Future studies of their abundances and formation mechanisms are warranted.

Table 2 summarizes the seasonally and annually averaged concentrations of the quantified OSs as well as their contributions to OM in 2015-2016 and 2018-2019. The average concentration of quantified OSs was $65.5 \pm 77.5 \mathrm{ng} \mathrm{m}^{-3}$ in 2015-2016 and 59.4 $\pm 79.7 \mathrm{ng} \mathrm{m}^{-3}$ in 2018-2019. Although there was little change in OS concentration in these two years, the contribution of OS to OM was larger in 2018-2019 $(0.66 \% \pm 0.56 \%)$ than in 2015-2016 $(0.57 \% \pm 0.56 \%)$, mainly due to a significant reduction of OM in 2018-2019. Since OS species are important tracers for SOAs (Surratt et al., 2007b; Gómez-González et al., 2008; Surratt et al., 2008; McNeill et al., 2012; Zhang et al., 2012; Surratt et al., 2010; Lin et al., 2013), an increase of OS / OM ratios 


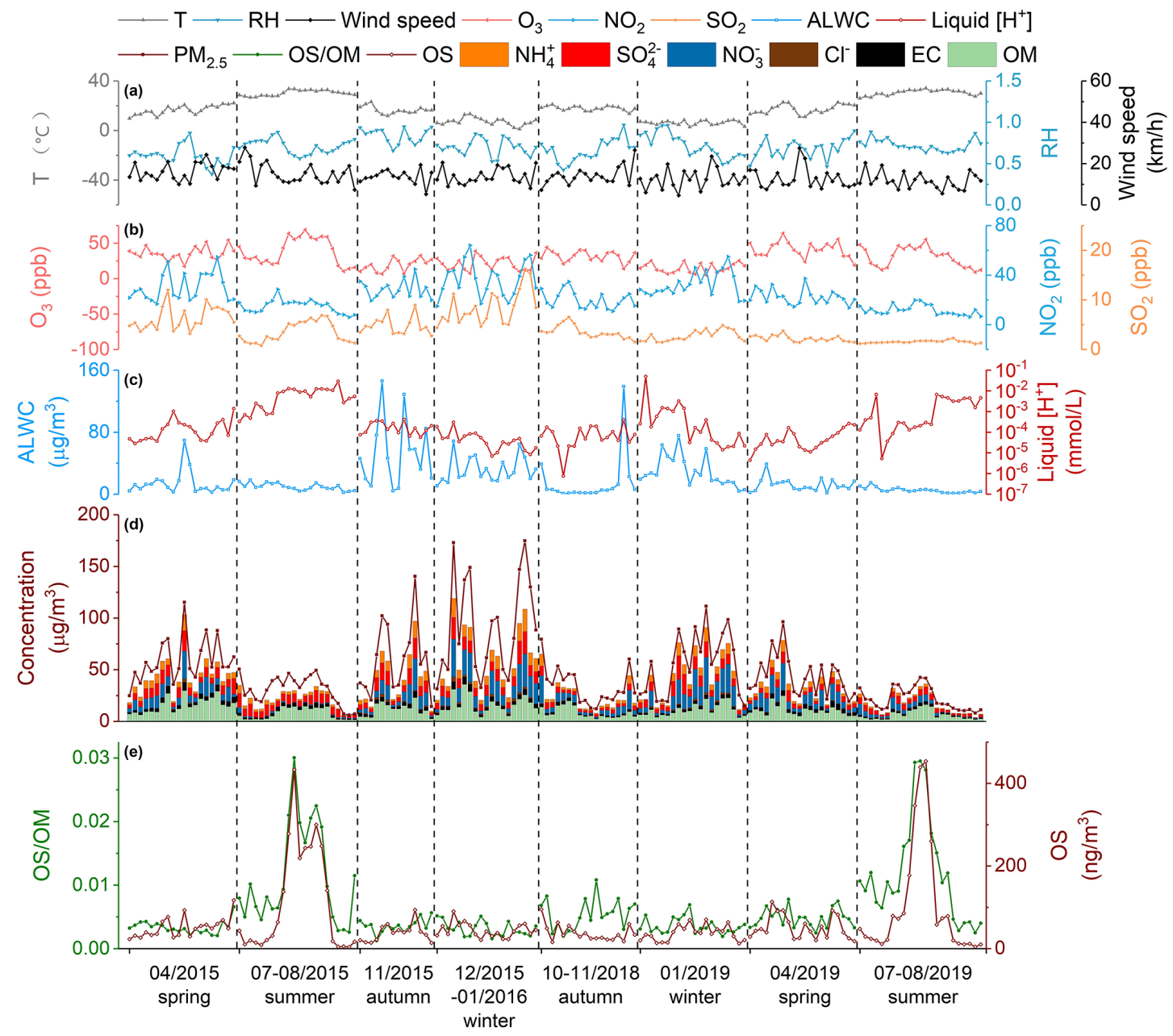

Figure 2. Time series of temperature, relative humidity $(\mathrm{RH})$, wind speed, $\mathrm{O}_{3}, \mathrm{NO}_{2}, \mathrm{SO}_{2}$, aerosol liquid water content (ALWC) and liquid $\left[\mathrm{H}^{+}\right]$; concentrations of particulate organic matter $(\mathrm{OM})$, elemental carbon (EC), sulfate, nitrate, chloride, ammonium; and the abundance of OSs and their contribution to OM in 2015-2016 and 2018-2019 in Shanghai.

Table 2. A summary of OS concentrations (in $\mathrm{n} \mathrm{m}^{-3}$ ) and their contribution to OM (OS / OM) in the four seasons in 2015-2016 and 2018-2019.

\begin{tabular}{lrr|rr}
\hline \multirow{2}{*}{ Season } & \multicolumn{2}{c|}{$2015-2016$} & \multicolumn{2}{c}{$2018-2019$} \\
\cline { 2 - 5 } & OS & OS / OM & OS & OS / OM \\
\hline All year & $65.5 \pm 77.5$ & $0.57 \% \pm 0.56 \%$ & $59.4 \pm 79.7$ & $0.66 \% \pm 0.56 \%$ \\
Spring & $51.1 \pm 24.4$ & $0.34 \% \pm 0.10 \%$ & $51.5 \pm 28.8$ & $0.48 \% \pm 0.15 \%$ \\
Summer & $114.1 \pm 128.4$ & $1.13 \% \pm 0.78 \%$ & $102.1 \pm 137.7$ & $1.18 \% \pm 0.81 \%$ \\
Autumn & $38.2 \pm 21.7$ & $0.36 \% \pm 0.11 \%$ & $38.0 \pm 20.0$ & $0.54 \% \pm 0.24 \%$ \\
Winter & $44.5 \pm 17.5$ & $0.32 \% \pm 0.12 \%$ & $37.3 \pm 18.4$ & $0.36 \% \pm 0.13 \%$ \\
\hline
\end{tabular}

in 2018-2019 implies an enhanced contribution of SOAs to organic aerosols (OAs) in Shanghai. A previous study by Ma et al. (2014) reported an average OS concentration in urban Shanghai in 2012/2013 of about $8.6 \mathrm{ng} \mathrm{m}^{-3}$, substantially smaller than the concentration reported here. This is likely due to the different number of OS species quantified
(17 vs. 35$)$ and the different OS standards used (octyl and benzyl sulfates vs. seven authentic or surrogate standards) in the Ma et al. (2014) and the present studies. As can be seen in Fig. 2e and Table 2, the OS concentration and OS / OM ratio both showed a strong seasonal variation and peaked in summer. The concentration of OS and its contribution 


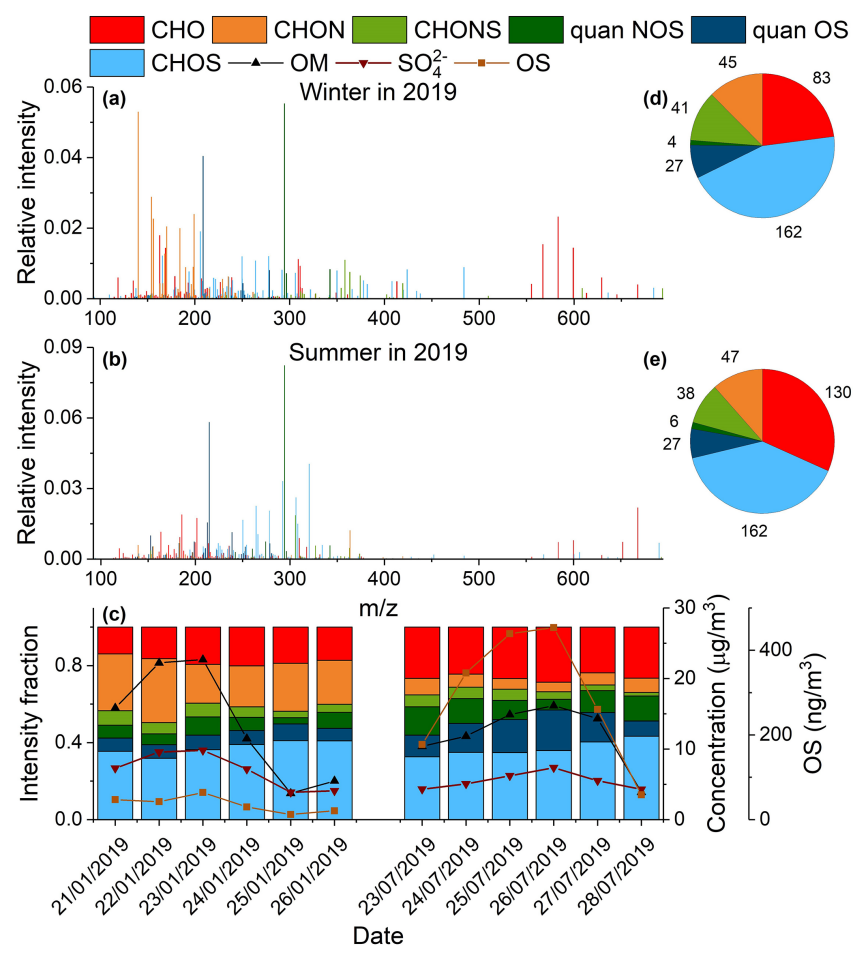

Figure 3. Average mass spectra of detected compounds in ambient aerosols during typical (a) wintertime (21-26 January 2019) and (b) summertime (23-28 July 2019) pollution episodes in Shanghai. The detected compounds were classified into six categories: $\mathrm{CHO}$, CHON, CHOS, CHONS, quantified NOS, and quantified OSs. The CHOS and CHONS categories excluded quantified OSs and NOSs, respectively. (c) Intensity fraction of different compound categories as well as the time series of $\mathrm{OM}, \mathrm{SO}_{4}^{2-}$, and $\mathrm{OS}$ concentrations during two pollution episodes in 2019. (d, e) Number of compounds detected in each category during the pollution episodes in winter and summer, respectively.

to $\mathrm{OM}$ in summertime Shanghai (on average $114.1 \mathrm{ng} \mathrm{m}^{-3}$ and $1.13 \%$ in July 2015 and $102.1 \mathrm{ng} \mathrm{m}^{-3}$ and $1.18 \%$ in July 2019) were larger or comparable to those observed in Beijing (55.2 $\mathrm{ng} \mathrm{m}^{-3}, 0.42 \%$ ) (Wang et al., 2018) and Birmingham, Alabama (205.4 $\mathrm{ng} \mathrm{m}^{-3}, 2 \%$ of OC) (Rattanavaraha et al., 2016), but significantly lower than those observed in Atlanta, GA (2366.4 $\mathrm{ng} \mathrm{m}^{-3}, 16.5 \%$ of OC), and Centreville, $\mathrm{AL}\left(812 \mathrm{ng} \mathrm{m}^{-3}, 7.3 \%\right.$ of OC) (Hettiyadura et al., 2019), where the production of OSs and SOAs is dominated by the oxidation of biogenic emissions. The contribution of OSs to $\mathrm{OM}$ in wintertime Shanghai (on average $0.32 \%$ in January 2016 and $0.36 \%$ in January 2019) was larger than that observed in Xi' an $(\sim 0.2 \%)$ (Huang et al., 2018), though the quantified OS concentrations in the two regions were comparable. This may suggest a stronger secondary formation of OAs in Shanghai than in Xi'an, consistent with independent measurements by Huang et al. (2014).

To further characterize the seasonality and interannual variability of OSs, as well as their origin and formation mechanisms, the quantified OSs were assigned to four different source categories based on their molecular composition and literature data (Surratt et al., 2008, 2007a; Nozière et al., 2010; Surratt et al., 2010; Schindelka et al., 2013; Zhang et al., 2014; Riva et al., 2015, 2016b; Blair et al., 2017; Nestorowicz et al., 2018). The OS species for each OS source category are listed in Table 1 and the seasonal and interannual variations in the abundance of grouped and individual OSs are shown in Fig. 4 and Table S5 in the Supplement, respectively.

\subsubsection{Isoprene-derived organosulfates}

The isoprene-derived OSs (hereafter referred to as $\mathrm{OS}_{\mathrm{i}}$ ) include $10 \mathrm{C}_{4-5}$ species and one dimeric species $\left(\mathrm{C}_{7} \mathrm{H}_{9} \mathrm{O}_{7} \mathrm{~S}^{-}\right)$. The average concentration of $\mathrm{OS}_{\mathrm{i}}$ in summer was $76.5 \pm 93.4 \mathrm{ng} \mathrm{m}^{-3}$ for $2015-2016$ and $68.4 \pm 102.2 \mathrm{ng} \mathrm{m}^{-3}$ for 2018-2019, significantly larger than the concentrations (10.4-17.1 $\mathrm{ng} \mathrm{m}^{-3}$ ) in other seasons (Fig. 4a). Similar strong seasonality of $\mathrm{OS}_{\mathrm{i}}$ was also observed in suburban areas in the mid-Atlantic United States (Meade et al., 2016) and the Pearl River Delta (PRD) in southern China (He et al., 2014). The significantly increased production of $\mathrm{OS}_{\mathrm{i}}$ in summer is mainly a result of enhanced isoprene emissions (Guenther et al., 1995) and photochemistry due to strong solar radiation and high temperatures in this warmer season.

The most abundant $\mathrm{OS}_{\mathrm{i}}$ species was 2-MTS $\left(\mathrm{C}_{5} \mathrm{H}_{11} \mathrm{O}_{7} \mathrm{~S}^{-}\right)$, produced by reactive uptake of IEPOX on sulfate during the photooxidation of isoprene under low- $\mathrm{NO}_{x}$ conditions (Surratt et al., 2010). The average concentration of 2-MTS was $\sim 31 \mathrm{ng} \mathrm{m}^{-3}$ in summer, contributing about $45 \%$ of the $\mathrm{OS}_{\mathrm{i}}$, whereas it decreased to $0.4-1.3 \mathrm{ng} \mathrm{m}^{-3}$ in other seasons, accounting for only $4 \%-10 \%$ of the $\mathrm{OS}_{\mathrm{i}}$ in 2015-2016 and 2018-2019 (see Table S5 in the Supplement). In addition, 2-methylglyceric acid sulfate (2-MAS, $\mathrm{C}_{4} \mathrm{H}_{7} \mathrm{O}_{7} \mathrm{~S}^{-}$) was abundantly detected with an average concentration of $4.5 \mathrm{ng} \mathrm{m}^{-3}$ in summer and $1.0-2.2 \mathrm{ng} \mathrm{m}^{-3}$ in other seasons during both sampling years. 2-MAS is formed from reactive uptake of methacrylic acid epoxide (MAE) (Lin et al., 2013) and hydroxymethyl-methyl-lactone (HMML) (Nguyen et al., 2015) on sulfate aerosols during isoprene photooxidation under high- $\mathrm{NO}_{x}$ conditions. It is worthwhile noting that the concentration ratio of 2-MTS/2-MAS in summer (6.8-7.8) is substantially larger than in other seasons $(0.31-0.78)$. This is consistent with a dramatic reduction of $\mathrm{NO}_{x}$ levels (e.g., $\left.\mathrm{NO}_{2}\right)$ in summer $(\sim 13 \mathrm{ppb})$ compared to other seasons ( $\sim 24-34 \mathrm{ppb})$ (see Table S1 in the Supplement). Furthermore, the $\mathrm{NO}_{x}$-influenced oxidation pathways may not be conducive to 2-MAS formation in summer, given that the formation of reactive intermediates such as MAE is unfavorable at high temperatures, owing to enhanced thermal decomposition of its precursor methacryloyl peroxynitrate (MPAN) (Worton et al., 2013). 2-MTS and 2-MAS are key tracers for isoprene-derived SOAs under low- and high- $\mathrm{NO}_{x}$ 


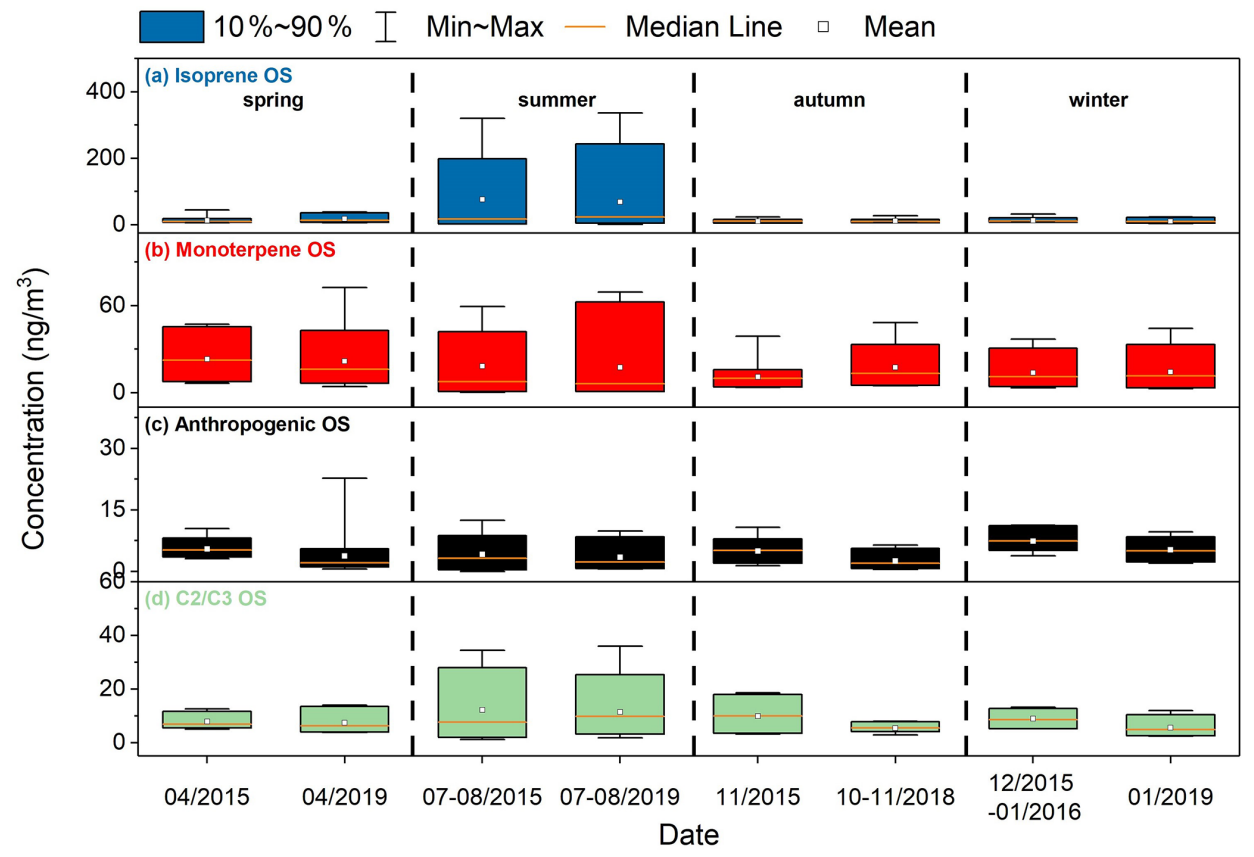

Figure 4. Concentrations of different types of the quantified OSs over the four seasons in 2015-2016 and 2018-2019.

conditions, respectively (Surratt et al., 2010; Lin et al., 2013; Nguyen et al., 2015). The dramatically larger ratios of 2-MTS/2-MAS in summer than in other seasons, therefore, strongly suggest that the low- $\mathrm{NO}_{x}$ oxidation pathways dominated the production of isoprene-derived SOAs in summer, while the processes favorable under high- $\mathrm{NO}_{x}$ conditions were important for SOA formation in other seasons. We note that the 2-MTS/2-MAS ratios observed in summertime Shanghai are smaller than those (17.0-33.8) observed in less polluted environments such as the southeastern United States (Hettiyadura et al., 2019; Budisulistiorini et al., 2015; Riva et al., 2019) but significantly larger than those (0.55-1.57) observed in Beijing (Wang et al., 2018; Bryant et al., 2020) and the PRD region of China (He et al., 2018).

Other abundant $\mathrm{OS}_{\mathrm{i}}$ species include $\mathrm{C}_{5} \mathrm{H}_{7} \mathrm{O}_{7} \mathrm{~S}^{-}$, $\mathrm{C}_{5} \mathrm{H}_{9} \mathrm{O}_{7} \mathrm{~S}^{-}$, and $\mathrm{C}_{4} \mathrm{H}_{7} \mathrm{O}_{6} \mathrm{~S}^{-}$. The $\mathrm{C}_{5} \mathrm{H}_{7} \mathrm{O}_{7} \mathrm{~S}^{-}$and $\mathrm{C}_{5} \mathrm{H}_{9} \mathrm{O}_{7} \mathrm{~S}^{-}$species can be produced by photooxidation of isoprene (Surratt et al., 2008; Nestorowicz et al., 2018) and/or the oxidative aging of 2-MTS (Hettiyadura et al., 2015; Chen et al., 2020). $\mathrm{C}_{4} \mathrm{H}_{7} \mathrm{O}_{6} \mathrm{~S}^{-}$can be generated both from sulfate radical reaction with MACR or MVK (Nozière et al., 2010; Schindelka et al., 2013; Wach et al., 2019) and isoprene photooxidation (Lin et al., 2013; Surratt et al., 2007a; Nestorowicz et al., 2018). $\mathrm{C}_{5} \mathrm{H}_{7} \mathrm{O}_{7} \mathrm{~S}^{-}$ and $\mathrm{C}_{4} \mathrm{H}_{7} \mathrm{O}_{6} \mathrm{~S}^{-}$are also consistent in molecular formula with the OS species formed from the photooxidation of diesel fuel vapors (Blair et al., 2017). However, these two species had moderate to strong correlations with MT-OS and $\mathrm{C}_{5} \mathrm{H}_{9} \mathrm{O}_{7} \mathrm{~S}^{-}$in different seasons except for autumn $\left(\mathrm{C}_{5} \mathrm{H}_{7} \mathrm{O}_{7} \mathrm{~S}^{-}, r=0.68-0.96 ; \quad \mathrm{C}_{4} \mathrm{H}_{7} \mathrm{O}_{6} \mathrm{~S}^{-}, r=0.62-0.96\right)$, indicating that they are mainly derived from isoprene oxidation. We note that the five most abundant $\mathrm{OS}_{\mathrm{i}}$ species discussed above were moderately correlated with EC and $\mathrm{CO}$ in winter $(r=0.5-0.67)$, suggesting that there might be anthropogenic sources of isoprene in winter. Borbon et al. (2001) measured the hourly isoprene concentration at an urban site in Lille, France, for two years and found that isoprene was largely derived from vehicle emissions in winter. In addition to OS species, two isoprene-derived NOSs $\left(\mathrm{C}_{5} \mathrm{H}_{10} \mathrm{NO}_{9} \mathrm{~S}^{-}\right.$and $\left.\mathrm{C}_{5} \mathrm{H}_{8} \mathrm{NO}_{10} \mathrm{~S}^{-}\right)$were observed, particularly in summer.

\subsubsection{Monoterpene-derived organosulfates}

The monoterpene-derived OSs (hereafter referred to as $\mathrm{OS}_{\mathrm{m}}$ ) include seven $\mathrm{C}_{7-10}$ OS species and three $\mathrm{C}_{9-10}$ NOS species. Compared to the $\mathrm{OS}_{\mathrm{i}}$, the $\mathrm{OS}_{\mathrm{m}}$ showed a weaker seasonal variation and a relatively larger abundance except in summer (Fig. 4b). This is consistent with the fact that isoprene emissions have stronger seasonal variability than monoterpene emissions (Guenther et al., 1995). The seasonally averaged concentrations of $\mathrm{OS}_{\mathrm{m}}$ were higher in spring and summer but lower in autumn and winter. This is different from previous observations in 2012/2013 in Shanghai by $\mathrm{Ma}$ et al. (2014). They found that the $\mathrm{OS}_{\mathrm{m}}$ were most abundant in summer, followed by autumn, winter, and spring. The differences in seasonal variations of $\mathrm{OS}_{\mathrm{m}}$ observed by the two studies may be attributed to different meteorological and chemical conditions that affected precursor emissions and the chemistry of $\mathrm{OS}_{\mathrm{m}}$ formation over the sampling periods. Given that the $\mathrm{OS}_{\mathrm{m}}$ concentration had an obvious daily varia- 
tion, the number of samples collected would significantly affect the seasonally averaged concentration. As such, the difference in the number of samples collected each season (1820 samples in this study vs. six samples within three days in Ma et al., 2014) may also contribute to the different seasonality observed in the two studies.

The NOS species, such as $\mathrm{C}_{10} \mathrm{H}_{16} \mathrm{NO}_{7} \mathrm{~S}^{-}, \mathrm{C}_{9} \mathrm{H}_{14} \mathrm{NO}_{8} \mathrm{~S}^{-}$, and $\mathrm{C}_{10} \mathrm{H}_{16} \mathrm{NO}_{10} \mathrm{~S}^{-}$, were the most abundant $\mathrm{OS}_{\mathrm{m}}$ species, which mainly arise from monoterpene photooxidation in the presence of $\mathrm{NO}_{x}$ or nighttime $\mathrm{NO}_{3}$ chemistry (Surratt et al., 2008; Iinuma et al., 2007a). The concentrations of these three NOSs were all lower in summer than in spring and autumn (Table S5 in the Supplement), consistent with the seasonal trend of $\mathrm{NO}_{x}$ concentrations (Fig. 2 and Table S1 in the Supplement). Similar seasonal variations for these NOS species were also observed in the PRD region of China (He et al., 2014) and the mid-Atlantic United States (Meade et al., 2016). Among the NOS species, $\mathrm{C}_{10} \mathrm{H}_{16} \mathrm{NO}_{7} \mathrm{~S}^{-}$was most abundant, contributing $22 \%-48 \%$ to the $\mathrm{OS}_{\mathrm{m}}$. This species had an annual average concentration of $6.2 \pm 6.5 \mathrm{ng} \mathrm{m}^{-3}$ in 2015-2016 and $5.5 \pm 6.2 \mathrm{ng} \mathrm{m}^{-3}$ in 2018-2019, which is comparable to the concentrations observed in Beijing $\left(12 \mathrm{ng} \mathrm{m}^{-3}\right.$ ) (Wang et al., 2018) and Atlanta, GA $\left(9.0 \mathrm{ng} \mathrm{m}^{-3}\right.$ ) (Hettiyadura et al., 2019), but much lower than that observed in the PRD region of China (52.4 $\mathrm{ng} \mathrm{m}^{-3}$ in summer and $151 \mathrm{ng} \mathrm{m}^{-3}$ in autumn) (He et al., 2014). The prevalence of monoterpene-derived NOSs in Shanghai as observed in this study is consistent with recent observations that monoterpenes accounted for up to $60 \%$ of nighttime $\mathrm{NO}_{3}$ radical loss in the YRD region of China (H. C. Wang et al., 2020).

The most abundant nitrogen-free $\mathrm{OS}_{\mathrm{m}}$ species was $\mathrm{C}_{10} \mathrm{H}_{15} \mathrm{O}_{7} \mathrm{~S}^{-}(m / z$ 279.0538), which was shown to be produced from the photooxidation of monoterpenes (Surratt et al., 2008) or sulfate radical reaction with $\alpha$-pinene (Nozière et al., 2010). Although $\mathrm{C}_{10} \mathrm{H}_{15} \mathrm{O}_{7} \mathrm{~S}^{-}$is consistent in molecular composition with the OS species formed by the photooxidation of cyclodecane in the presence of sulfate aerosols (Riva et al., 2016b), its moderate to strong correlation $(r=0.51-0.93)$ with the three monoterpene-derived NOSs in all seasons except for winter suggests that it is mainly derived from monoterpene oxidation. The concentration of $\mathrm{C}_{10} \mathrm{H}_{15} \mathrm{O}_{7} \mathrm{~S}^{-}$was, on average, $3.0 \pm 3.0 \mathrm{ng} \mathrm{m}^{-3}$ in 2015-2016, lower than that $\left(4.0 \pm 3.4 \mathrm{ng} \mathrm{m}^{-3}\right)$ in 20182019. In contrast to the NOS species, the $\mathrm{C}_{10} \mathrm{H}_{15} \mathrm{O}_{7} \mathrm{~S}^{-}$ species was most abundant in summer in both years, again suggesting a strong contribution of low- $\mathrm{NO}_{x}$ chemistry in OS and SOA formation in summer.

\subsubsection{Anthropogenic organosulfates}

The quantified anthropogenic OSs (hereafter referred to as $\left.\mathrm{OS}_{\mathrm{a}}\right)$ in this study include phenyl sulfate $\left(\mathrm{C}_{6} \mathrm{H}_{5} \mathrm{O}_{4} \mathrm{~S}^{-}\right)$, benzyl sulfate $\left(\mathrm{C}_{7} \mathrm{H}_{7} \mathrm{O}_{4} \mathrm{~S}^{-}\right), \mathrm{C}_{8} \mathrm{H}_{17} \mathrm{O}_{4} \mathrm{~S}^{-}$, as well as $\mathrm{C}_{4} \mathrm{H}_{7} \mathrm{O}_{4} \mathrm{~S}^{-}, \mathrm{C}_{5} \mathrm{H}_{7} \mathrm{O}_{6} \mathrm{~S}^{-}$, and $\mathrm{C}_{6} \mathrm{H}_{9} \mathrm{O}_{6} \mathrm{~S}^{-}$. The annual av- erage concentrations of $\mathrm{OS}_{\mathrm{a}}$ in 2015-2016 and 2018-2019 were $5.6 \pm 2.8$ and $3.8 \pm 3.3 \mathrm{ng} \mathrm{m}^{-3}$, respectively. Although the concentration of quantified $\mathrm{OS}_{\mathrm{a}}$ decreased in 2018-2019, we are not sure whether the total concentration of $\mathrm{OS}_{\mathrm{a}}$ decreased because only a small fraction of $\mathrm{OS}_{\mathrm{a}}$ was quantified. The interannual variation of $\mathrm{OS}_{\mathrm{a}}$ warrants further study. As shown in Fig. 4c, the quantified $\mathrm{OS}_{\mathrm{a}}$ concentration was substantially smaller compared to the biogenic OS concentration. In addition, the $\mathrm{OS}_{\mathrm{a}}$ concentration had little seasonal variations in both 2015-2016 and 2018-2019. Among the quantified $\mathrm{OS}_{\mathrm{a}}, \mathrm{C}_{4} \mathrm{H}_{7} \mathrm{O}_{4} \mathrm{~S}^{-}$was most abundant with an annual average concentration of $2.0 \pm 1.5 \mathrm{ng} \mathrm{m}^{-3}$ in 2015-2016 and $1.8 \pm 2.6 \mathrm{ng} \mathrm{m}^{-3}$ in 2018-2019, which is comparable to the concentrations in Atlanta,GA (Hettiyadura et al., 2019). Blair et al. (2017) found that photooxidation of diesel vapors in the presence of $\mathrm{SO}_{2}$ can form $\mathrm{C}_{4} \mathrm{H}_{7} \mathrm{O}_{4} \mathrm{~S}^{-}, \mathrm{C}_{5} \mathrm{H}_{7} \mathrm{O}_{6} \mathrm{~S}^{-}$, and $\mathrm{C}_{6} \mathrm{H}_{9} \mathrm{O}_{6} \mathrm{~S}^{-}$species. The $\mathrm{C}_{8} \mathrm{H}_{17} \mathrm{O}_{4} \mathrm{~S}^{-}$species had the same retention time as the octyl sulfate standard in the LC column, suggesting it is a long-chain aliphatic OS. This OS species was correlated with $\mathrm{C}_{5} \mathrm{H}_{7} \mathrm{O}_{6} \mathrm{~S}^{-}$and $\mathrm{C}_{6} \mathrm{H}_{9} \mathrm{O}_{6} \mathrm{~S}^{-}$, which were potential diesel vapor-derived OSs. Phenyl sulfate and benzyl sulfate may be produced by photooxidation of naphthalene and 2methylnaphthalene (Riva et al., 2015) and/or by sulfate radical reaction with aromatic compounds such as benzoic acid and toluene in the aqueous phase (Huang et al., 2020), but phenyl sulfate was only detected in 42 out of 75 samples in 2015-2016 and 8 out of 81 samples in 2018-2019, primarily in winter. The benzyl sulfate concentrations in 20152016 and 2018-2019 were $0.4 \pm 0.1$ and $0.2 \pm 0.10 \mathrm{ng} \mathrm{m}^{-3}$, respectively, which were higher than the observations in springtime Lahore, Pakistan (Staudt et al., 2014), and in wintertime Xi' an, China (Huang et al., 2018). Benzyl sulfate had a strong correlation with phenyl sulfate and was also correlated with $\mathrm{C}_{6} \mathrm{H}_{9} \mathrm{O}_{6} \mathrm{~S}^{-}$and $\mathrm{C}_{8} \mathrm{H}_{17} \mathrm{O}_{4} \mathrm{~S}^{-}$.

\subsection{4 $C_{2}$ or $C_{3}$ organosulfates}

The OS species with two or three carbon atoms are grouped together since many of them are considered to have both biogenic and anthropogenic origins. The $\mathrm{C}_{2}$ and $\mathrm{C}_{3}$ OSs quantified in this study include $\mathrm{C}_{2} \mathrm{H}_{3} \mathrm{O}_{6} \mathrm{~S}^{-}(\mathrm{m} / z$ 154.9650), $\mathrm{C}_{3} \mathrm{H}_{5} \mathrm{O}_{5} \mathrm{~S}^{-}\left(\mathrm{m} / \mathrm{z}\right.$ 152.9858), $\mathrm{C}_{3} \mathrm{H}_{5} \mathrm{O}_{6} \mathrm{~S}^{-}(\mathrm{m} / z$ 168.9807), $\mathrm{C}_{2} \mathrm{H}_{3} \mathrm{O}_{5} \mathrm{~S}^{-}$(m/z 138.9701), $\mathrm{C}_{3} \mathrm{H}_{5} \mathrm{O}_{4} \mathrm{~S}^{-}$(m/z 136.9909), and $\mathrm{C}_{3} \mathrm{H}_{7} \mathrm{O}_{5} \mathrm{~S}^{-}\left(\mathrm{m} / z\right.$ 155.0014). The $\mathrm{C}_{2}$ and $\mathrm{C}_{3}$ OS species accounted for, on average, $19 \%$ of the quantified OS concentrations and overall they were more abundant in summer than in other seasons in 2015-2016 and 2018-2019 (Fig. 4d). The $\mathrm{C}_{2} \mathrm{H}_{3} \mathrm{O}_{6} \mathrm{~S}^{-}, \mathrm{C}_{3} \mathrm{H}_{5} \mathrm{O}_{5} \mathrm{~S}^{-}$, and $\mathrm{C}_{3} \mathrm{H}_{5} \mathrm{O}_{6} \mathrm{~S}^{-}$ species, which were previously assigned to glycolic acid sulfate (GAS), hydroxyacetone sulfate (HAS), and lactic acid sulfate (LAS), respectively (Olson et al., 2011; Hettiyadura et al., 2017; Huang et al., 2018; Wang et al., 2018; Hettiyadura et al., 2019), were among the most abundant $\mathrm{C}_{2}$ or $\mathrm{C}_{3}$ OS species, together contributing $76 \%$ of 
the $\mathrm{C}_{2}$ and $\mathrm{C}_{3}$ OS concentrations during both sampling years. The concentration of $\mathrm{C}_{2} \mathrm{H}_{3} \mathrm{O}_{6} \mathrm{~S}^{-}$(GAS) was, on average, $2.9 \pm 2.2 \mathrm{ng} \mathrm{m}^{-3}$ in $2015-2016$ and $2.3 \pm 1.7 \mathrm{ng} \mathrm{m}^{-3}$ in 2018-2019, which was lower than the concentrations measured in Beijing (19.5 $\mathrm{ng} \mathrm{m}^{-3}$ ) (Wang et al., 2018), Xi'an (77.3 $\mathrm{ng} \mathrm{m}^{-3}$ ) (Huang et al., 2018), Atlanta, GA $\left(58.5 \mathrm{ng} \mathrm{m}^{-3}\right.$ ) (Hettiyadura et al., 2019), Centreville, AL (20.6 $\mathrm{ng} \mathrm{m}^{-3}$ ) (Hettiyadura et al., 2017), Lahore, Pakistan (11.3 $\left.\mathrm{ng} \mathrm{m}^{-3}\right)$, and Bakersfield, CA (4.5-5.4 $\left.\mathrm{ng} \mathrm{m}^{-3}\right)$ (Olson et al., 2011), and similar to that observed in Riverside, CA $\left(3.3 \mathrm{ng} \mathrm{m}^{-3}\right.$ ) (Olson et al., 2011). We note that if the underestimation (2-6 times) of concentration due to matrix effects is accounted for (see Sect. 2.5), the GAS concentration measured in Shanghai would be comparable to that in most of the regions mentioned above. The concentrations of $\mathrm{C}_{3} \mathrm{H}_{5} \mathrm{O}_{5} \mathrm{~S}^{-}$(HAS) and $\mathrm{C}_{3} \mathrm{H}_{5} \mathrm{O}_{6} \mathrm{~S}^{-}$(LAS) were quite similar, on average, 2.3 and $2.2 \mathrm{ng} \mathrm{m}^{-3}$ in 2015-2016 and 1.8 and $1.9 \mathrm{ng} \mathrm{m}^{-3}$ in 2018-2019, respectively, which were comparable to the concentrations observed in Beijing (2.2 and $4.4 \mathrm{ng} \mathrm{m}^{-3}$ ) (Wang et al., 2018) and Xi' an $\left(1.3 \mathrm{ng} \mathrm{m}^{-3}\right.$ for HAS) (Huang et al., 2018), but lower than those measured in Centreville, $\mathrm{AL}$ (5.8 and $16.5 \mathrm{ng} \mathrm{m}^{-3}$ ) (Hettiyadura et al., 2017), and Atlanta, GA (10.1 and $38.4 \mathrm{ng} \mathrm{m}^{-3}$ ) (Hettiyadura et al., 2019). $\mathrm{C}_{2} \mathrm{H}_{3} \mathrm{O}_{6} \mathrm{~S}^{-}, \mathrm{C}_{3} \mathrm{H}_{5} \mathrm{O}_{5} \mathrm{~S}^{-}, \mathrm{C}_{3} \mathrm{H}_{5} \mathrm{O}_{6} \mathrm{~S}^{-}$, and $\mathrm{C}_{2} \mathrm{H}_{3} \mathrm{O}_{5} \mathrm{~S}^{-}$were strongly correlated with most of the $\mathrm{OS}_{\mathrm{i}}$ species $\left(r=0.52-0.96\right.$ for $\mathrm{C}_{2} \mathrm{H}_{3} \mathrm{O}_{6} \mathrm{~S}^{-}, r=0.53-0.99$ for $\mathrm{C}_{3} \mathrm{H}_{5} \mathrm{O}_{5} \mathrm{~S}^{-}, r=0.53-0.90$ for $\mathrm{C}_{3} \mathrm{H}_{5} \mathrm{O}_{6} \mathrm{~S}^{-}$, and $r=$ 0.53-0.94 for $\mathrm{C}_{2} \mathrm{H}_{3} \mathrm{O}_{5} \mathrm{~S}^{-}$), indicating that they originated mainly from isoprene chemistry. This is in line with recent findings that a series of $\mathrm{C}_{2}$ or $\mathrm{C}_{3}$ OS species, including $\mathrm{C}_{2} \mathrm{H}_{3} \mathrm{O}_{6} \mathrm{~S}^{-}, \mathrm{C}_{3} \mathrm{H}_{5} \mathrm{O}_{6} \mathrm{~S}^{-}$, and $\mathrm{C}_{2} \mathrm{H}_{3} \mathrm{O}_{5} \mathrm{~S}^{-}$, can be produced by heterogeneous $\mathrm{OH}$ oxidation of particulate 2-MTS (Chen et al., 2020). The $\mathrm{C}_{3} \mathrm{H}_{5} \mathrm{O}_{4} \mathrm{~S}^{-}$species, proposed to contain an allyl group (Hettiyadura et al., 2017), was previously found to be produced by diesel photooxidation (Blair et al., 2017) and was correlated with anthropogenic OSs such as the potential diesel vapor-derived $\mathrm{OS}\left(\mathrm{C}_{8} \mathrm{H}_{17} \mathrm{O}_{4} \mathrm{~S}^{-}, \mathrm{C}_{4} \mathrm{H}_{7} \mathrm{O}_{4} \mathrm{~S}^{-}\right.$, $\mathrm{C}_{5} \mathrm{H}_{7} \mathrm{O}_{6} \mathrm{~S}^{-}$, and $\left.\mathrm{C}_{6} \mathrm{H}_{9} \mathrm{O}_{6} \mathrm{~S}^{-}, r=0.53-0.87\right)$ and benzyl sulfate $\left(\mathrm{C}_{7} \mathrm{H}_{7} \mathrm{O}_{4} \mathrm{~S}^{-}, r=0.49-0.88\right) . \mathrm{C}_{3} \mathrm{H}_{7} \mathrm{O}_{5} \mathrm{~S}^{-}$is likely an OS species containing one hydroxyl group (Hettiyadura et al., 2017); it was strongly correlated with $\mathrm{C}_{3} \mathrm{H}_{5} \mathrm{O}_{4} \mathrm{~S}^{-}$in all seasons and correlated with the diesel vapor-derived $\mathrm{OS}_{\mathrm{a}}$ $\left(\mathrm{C}_{6} \mathrm{H}_{9} \mathrm{O}_{6} \mathrm{~S}^{-}\right.$and $\left.\mathrm{C}_{8} \mathrm{H}_{17} \mathrm{O}_{4} \mathrm{~S}^{-}\right)$in spring and autumn, suggesting that it may be largely derived from the photooxidation of diesel vapors. This result is different from the observations in Atlanta, $\mathrm{GA}$, where $\mathrm{C}_{3} \mathrm{H}_{7} \mathrm{O}_{5} \mathrm{~S}^{-}$was correlated with most of the $\mathrm{OS}_{\mathrm{i}}$, leading to the suggestion that it was derived from the oxidation of isoprene (Hettiyadura et al., 2019). We note that the concentrations of the $\mathrm{C}_{3} \mathrm{H}_{5} \mathrm{O}_{4} \mathrm{~S}^{-}$ and $\mathrm{C}_{3} \mathrm{H}_{7} \mathrm{O}_{5} \mathrm{~S}^{-}$species decreased significantly from 2015 2016 to 2018-2019 (except for summer; see Table S5 in the Supplement), which is overall consistent with the interannual variations of $\mathrm{OS}_{\mathrm{a}}$ species. This further supports that these two OS species mainly originated from anthropogenic sources.

\subsection{Factors influencing organosulfate formation}

Laboratory and field studies have shown that aerosol properties such as acidity, sulfate concentration, and ALWC play important roles in the formation of OSs (Iinuma et al., 2007b; Chan et al., 2011; Surratt et al., 2007a,b; Liao et al., 2015; Hettiyadura et al., 2019; Riva et al., 2019). Here, we examined the influences of these factors as well as the level of oxidants and temperature on OS formation in ambient aerosols in Shanghai. Aerosol pH and ALWC were calculated using ISORROPIA-II (see Sect. 2.4). Figure 5 shows the OS concentration vs. the $\mathrm{O}_{x}$ level, sulfate concentration, aerosol $\mathrm{pH}$, and ALWC observed in the spring, autumn, and winter of 2015-2016 and 2018-2019. Since the OS concentrations in summer were significantly greater than in other seasons, they are plotted separately in Fig. 6. As shown in Figs. 5 and 6, the aerosol $\mathrm{pH}$ in Shanghai ranged between 1.5 and 5.3 in summer and between 2.5 and 6.1 in other seasons, which is overall within the $\mathrm{pH}$ range (2-6) reported for ambient aerosols in northern China (Liu et al., 2017; Shi et al., 2017; J. Ding et al., 2019; Song et al., 2019; Wang et al., 2018). A recent study by Zheng et al. (2020) suggested that aerosol pH levels in populated continental regions including eastern and northern China are widely buffered by ammonium/ammonia, where the variation in aerosol $\mathrm{pH}$ is mainly driven by the variation in ALWC and temperature. Therefore, we infer that the lower aerosol $\mathrm{pH}$ in summer compared to other seasons in Shanghai was mainly a result of decreased ALWC (Figs. 5 and $6 \mathrm{c}, \mathrm{d}$ ) and enhanced temperature (Fig. 2a). Decreased aerosol $\mathrm{pH}$ in summer compared to other seasons was also observed in Beijing (J. Ding et al., 2019) and the southeastern United States (Guo et al., 2015; Nah et al., 2018).

As can be seen in Fig. 5, the OS concentration in spring, autumn, and winter obviously increased with increasing $\mathrm{O}_{x}$ level, sulfate concentration, and aerosol acidity (Fig. 5a, b). A similar result was also found in Beijing, where most OS species were correlated strongly with the product of ozone and particulate sulfate $\left(\left[\mathrm{O}_{3}\right] \cdot\left[\mathrm{SO}_{4}^{2-}\right]\right)$ (Bryant et al., 2020). In addition, an overall positive correlation was observed between the OS concentration and ALWC (Fig. 5c, d). Therefore, it is likely that the OS species were mainly produced by acid-catalyzed heterogeneous and aqueous-phase reactions of oxidized organic compounds with sulfate in these seasons. Previous studies have shown that elevated ALWC could inhibit OS production by decreasing aerosol acidity through dilution (Lewandowski et al., 2015; Nestorowicz et al., 2018). However, as the increase of ALWC was accompanied by elevated sulfate concentration, such a decrease in aerosol acidity was not observed in the present study (Fig. 5c, d). Alternatively, the increased ALWC likely promoted the mass transfer of oxidized organics into the aerosol phase, thereby enhancing OS formation. We note that the observations with moderate to high ALWC but relatively low OS concentration (triangle data points in Fig. 5c, d) were associated with low 

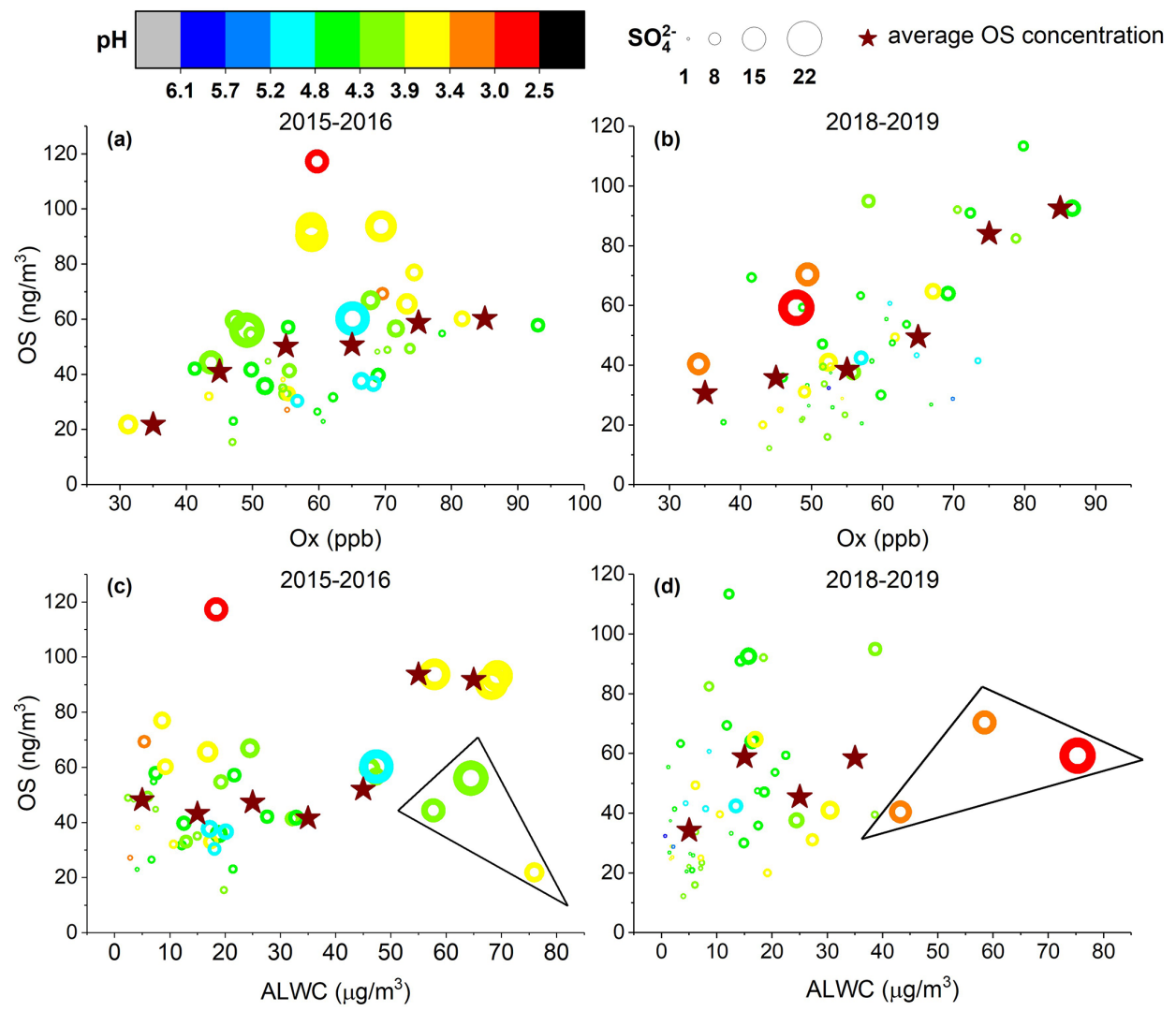

Figure 5. Quantified OS concentrations as a function of (a, b) the level of $\mathrm{O}_{x}\left(\mathrm{O}_{x}=\mathrm{O}_{3}+\mathrm{NO}_{2}\right)$ and (c, $\left.\mathbf{d}\right)$ aerosol liquid water content (ALWC) in 2015-2016 and 2018-2019, except for summer. The circles are colored according to the aerosol pH and their size is linearly scaled with the $\mathrm{SO}_{4}^{2-}$ concentration. The markers inside the triangle indicate the observations with low $\mathrm{O}_{x}$ levels $(<50 \mathrm{ppb})$. The measured OS concentrations within regular $\mathrm{O}_{x}$ or ALWC intervals (every 10 unit lengths) were averaged to more obviously demonstrate the trend (star symbols).

$\mathrm{O}_{x}$ levels $(<50 \mathrm{ppb})$ that significantly limited the oxidation of VOC precursors and hence the formation of OS.

As seen in Fig. 6, the OS production in summer increased dramatically with rising $\mathrm{O}_{x}$ concentration. In addition, high OS concentrations were associated with high ambient temperatures, which can enhance emissions of biogenic precursors and the production of $\mathrm{O}_{x}$. While the aerosol acidity effect on OS production in summer was still evident, the influence of sulfate and ALWC was not as obvious as in other seasons. This is likely because the OS production in summer was driven by the strong emissions and fast photochemistry of VOC precursors. It is noteworthy that the sulfate concentrations, ALWC, and aerosol acidities were overall higher in 2015-2016 than in 2018-2019, but the OS concentrations were similar. This implies that the $\mathrm{O}_{x}$ level is a driving factor for OS formation in ambient aerosols in Shanghai. Very recently, a similar oxidant effect on OS formation was also observed in urban Beijing (Bryant et al., 2020). Therefore, mitigation of $\mathrm{O}_{x}$ pollution may effectively reduce the production of OSs and SOAs in Chinese megacities.

\section{Conclusions}

In this study, we collected ambient $\mathrm{PM}_{2.5}$ filter samples over four seasons in 2015-2016 and 2018-2019 in urban Shanghai, China, and comprehensively characterized the sulfurcontaining organic compounds (CHOS and CHONS) in these $\mathrm{PM}_{2.5}$ samples using UPLC-ESI-QToFMS. The CHOS and CHONS species accounted for a large fraction of the ion signals for organic compounds in ambient $\mathrm{PM}_{2.5}$. Using a set of authentic and surrogate OS standards, we quantified the abundance of 29 OS and 6 NOS species in ambient aerosols. We found that there was no strong change in the OS concentration in 2018-2019 (59.4 $\left.\pm 79.7 \mathrm{ng} \mathrm{m}^{-3}\right)$ compared to that in 2015-2016 $\left(65.5 \pm 77.5 \mathrm{ng} \mathrm{m}^{-3}\right)$, though the OM concentration decreased by $29 \%$ between 2015-2016 $\left(12.7 \pm 8 \mu \mathrm{g} \mathrm{m}^{-3}\right)$ and 2018-2019 $\left(9 \pm 5.5 \mu \mathrm{g} \mathrm{m}^{-3}\right)$. As a result, the annual average contribution of quantified OSs to OM increased from $0.57 \%$ in $2015-2016$ to $0.66 \%$ in $2018-$ 2019, suggesting an enhanced contribution of SOAs to OM in Shanghai in recent years. The $\mathrm{OS}_{\mathrm{i}}$ and $\mathrm{OS}_{\mathrm{m}}$ accounted for, on average, $36.3 \%$ and $31.0 \%$ of the quantified OS concen- 

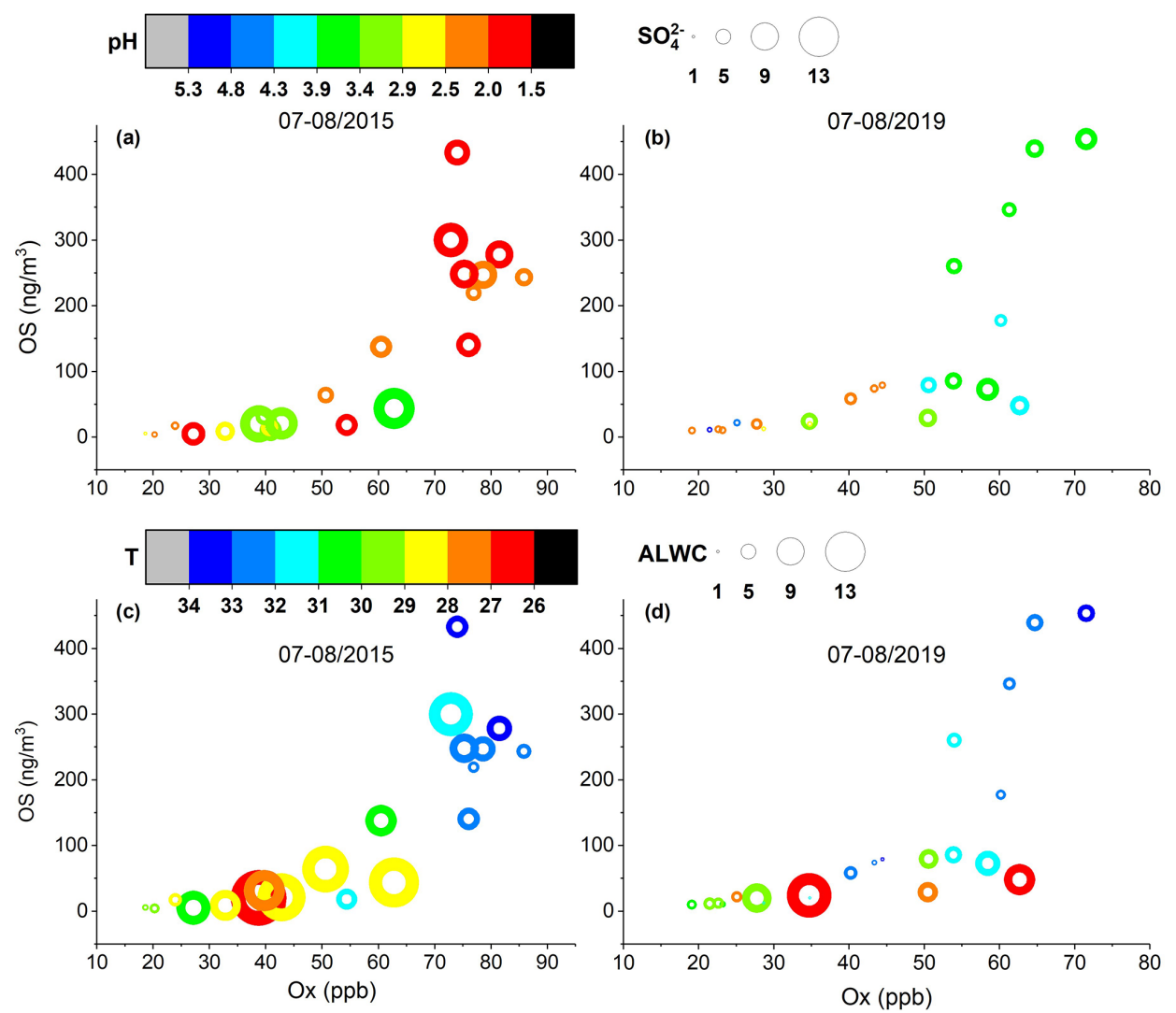

Figure 6. Quantified OS concentrations as a function of the $\mathrm{O}_{x}$ level in the summer of (a, c) 2015 and (b, d) 2019. The color of the circles in (a) and (b) indicates the aerosol pH and their size is linearly scaled with the $\mathrm{SO}_{4}^{2-}$ concentration. The color of the circles in (c) and (d) indicates ambient temperature and their size is linearly scaled with the aerosol liquid water content (ALWC).

trations, respectively, during both sampling years, indicating a significant contribution of biogenic emissions to SOAs in Shanghai. The abundance of $\mathrm{OS}_{\mathrm{i}}$ had strong seasonality and was significantly higher in summer $\left(76.5 \pm 93.4 \mathrm{ng} \mathrm{m}^{-3}\right.$ in 2015-2016 and $68.4 \pm 102.2 \mathrm{ng} \mathrm{m}^{-3}$ in 2018-2019) than in other seasons $\left(10.4-17.1 \mathrm{ng} \mathrm{m}^{-3}\right)$. The $\mathrm{OS}_{\mathrm{m}}$ concentration showed a weaker seasonal variation and was relatively higher in spring and summer than in autumn and winter. In contrast, the quantified $\mathrm{OS}_{\mathrm{a}}$ had little seasonal variations and decreased by $32 \%$ from $2015-2016$ to $2018-2019$. The $C_{2}$ and $\mathrm{C}_{3} \mathrm{OS}$ species that were more abundant in summer than in other seasons contributed, on average, $19 \%$ of the concentration of the quantified OS species. $\mathrm{C}_{2} \mathrm{H}_{3} \mathrm{O}_{6} \mathrm{~S}^{-}$(GAS), $\mathrm{C}_{3} \mathrm{H}_{5} \mathrm{O}_{5} \mathrm{~S}^{-}$(HAS), and $\mathrm{C}_{3} \mathrm{H}_{5} \mathrm{O}_{6} \mathrm{~S}^{-}$(LAS), which were derived mainly from isoprene chemistry, were the most abundant $\mathrm{C}_{2}$ or $\mathrm{C}_{3}$ OS species and together accounted for $76 \%$ of the $\mathrm{C}_{2}$ and $\mathrm{C}_{3}$ OS concentrations.

2-MTS was the most abundant OS species in summer. The dramatically larger 2-MTS/2-MAS ratios in summer (6.8$7.8)$ vs. other seasons $(0.31-0.78)$ imply that the reaction pathways prevalent under low- $\mathrm{NO}_{x}$ conditions (e.g., reactive uptake of IEPOX and photooxidation of isoprene hydroxy hydroperoxides (ISOPOOH)) dominated the produc- tion of $\mathrm{OS}_{\mathrm{i}}$ and isoprene-derived SOAs in summer, while the processes favorable under high- $\mathrm{NO}_{x}$ conditions play an important role in $\mathrm{OS}_{\mathrm{i}}$ and SOA formation in other seasons. The $\mathrm{C}_{10} \mathrm{H}_{16} \mathrm{NO}_{7} \mathrm{~S}^{-}$species derived from monoterpenes were the most abundant NOS species, with an annual average concentration of $6.2 \pm 6.5 \mathrm{ng} \mathrm{m}^{-3}$ in 2015-2016 and $5.5 \pm 6.2 \mathrm{ng} \mathrm{m}^{-3}$ in 2018-2019. This agrees well with previous observations that monoterpenes depleted about $60 \%$ of nighttime $\mathrm{NO}_{3}$ radicals in the YRD region of China (H. C. Wang et al., 2020).

In addition, we found that the abundance of OSs was overall positively correlated with the $\mathrm{O}_{x}$ level, sulfate concentration, aerosol acidity, and ALWC in spring, autumn, and winter, suggesting the production of OSs via acid-catalyzed aqueous-phase reactions of oxidized organic compounds on sulfate. However, OS production in summer was strongly driven by rising $\mathrm{O}_{x}$ and temperature, which could enhance the photochemistry and emissions of biogenic precursors. We further find that although sulfate concentrations, aerosol acidities, and ALWC were significantly lower in 2018-2019 than in 2015-2016, the production of OSs was largely sustained in 2018-2019 by the nearly unchanged $\mathrm{O}_{x}$ level that maintained the fast oxidation of VOC precursors. These re- 
sults imply that controlling $\mathrm{O}_{x}$ pollution may also effectively mitigate particulate organic matter pollution in eastern China.

It should be pointed out that GAS was likely underestimated by a factor of 2-6 as a result of the matrix effect during the analysis in our study. When accounting for this effect, it would be the second most abundant OS species after MT-OS. In addition, a large fraction of the CHOS signals that arose mainly from anthropogenic sources was not quantified due to the lack of proper OS standards in this study. Therefore, the OS concentration and its contribution to organic aerosols in Shanghai could be significantly greater. Future studies on the abundance, origin, and formation mechanisms of these unquantified OSs are warranted for a better understanding of the formation and evolution of OSs and SOAs in the atmosphere.

Data availability. The data presented in this work are available upon request from the corresponding author (yuezhao20@sjtu.edu.cn).

Supplement. The supplement related to this article is available online at: https://doi.org/10.5194/acp-21-2959-2021-supplement.

Author contributions. YZ designed and led the research. YaW, WZ, and ZC collected the ambient samples. YuW and JY provided the OS standards. JS conducted the ISORROPIA-II model calculation and YaW conducted the sample analysis. YZ and YaW processed the data and wrote the manuscript with contributions from all of the authors.

Competing interests. The authors declare that they have no conflict of interest.

Acknowledgements. Yue Zhao gratefully acknowledges the support by the Program for Professor of Special Appointment (Eastern Scholar) at Shanghai Institutions of Higher Learning. The authors would like to acknowledge the free availability of the meteorological data collected by the Shanghai Hongqiao international airport station and the concentration data of trace gases and $\mathrm{PM}_{2.5}$ measured by the state-controlled air quality monitoring station on the Xuhui Campus of Shanghai Normal University.

Financial support. This research has been supported by the National Natural Science Foundation of China (grant no. 21806104), the Science and Technology Commission of Shanghai Municipality (grant no. 19DZ1205004), and the Key Program of MedicalEngineering Cross Research Fund of Shanghai Jiao Tong University (grant no. YG2019ZDA24).
Review statement. This paper was edited by Willy Maenhaut and reviewed by three anonymous referees.

\section{References}

Behera, S. N., Cheng, J., Huang, X., Zhu, Q., Liu, P., and Balasubramanian, R.: Chemical composition and acidity of sizefractionated inorganic aerosols of 2013-14 winter haze in Shanghai and associated health risk of toxic elements, Atmos. Environ., 122, 259-271, https://doi.org/10.1016/j.atmosenv.2015.09.053, 2015.

Blair, S. L., MacMillan, A. C., Drozd, G. T., Goldstein, A. H., Chu, R. K., Pasa-Tolic, L., Shaw, J. B., Tolic, N., Lin, P., Laskin, J., Laskin, A., and Nizkorodov, S. A.: Molecular characterization of organosulfur compounds in biodiesel and diesel fuel secondary organic aerosol, Environ. Sci. Technol., 51, 119-127, https://doi.org/10.1021/acs.est.6b03304, 2017.

Borbon, A., Fontaine, H., Veillerot, M., Locoge, N., Galloo, J. C., and Guillermo, R.: An investigation into the traffic-related fraction of isoprene at an urban location, Atmos. Environ., 35, 37493760, 2001.

Brüggemann, M., Poulain, L., Held, A., Stelzer, T., Zuth, C., Richters, S., Mutzel, A., van Pinxteren, D., Iinuma, Y., Katkevica, S., Rabe, R., Herrmann, H., and Hoffmann, T.: Realtime detection of highly oxidized organosulfates and BSOA marker compounds during the F-BEACh 2014 field study, Atmos. Chem. Phys., 17, 1453-1469, https://doi.org/10.5194/acp17-1453-2017, 2017.

Brüggemann, M., Xu, R. S., Tilgner, A., Kwong, K. C., Mutzel, A., Poon, H. Y., Otto, T., Schaefer, T., Poulain, L., Chan, M. N., and Herrmann, H.: Organosulfates in ambient aerosol: state of knowledge and future research directions on formation, abundance, fate, and importance, Environ. Sci. Technol., 54, 37673782, https://doi.org/10.1021/acs.est.9b06751, 2020.

Bryant, D. J., Dixon, W. J., Hopkins, J. R., Dunmore, R. E., Pereira, K. L., Shaw, M., Squires, F. A., Bannan, T. J., Mehra, A., Worrall, S. D., Bacak, A., Coe, H., Percival, C. J., Whalley, L. K., Heard, D. E., Slater, E. J., Ouyang, B., Cui, T., Surratt, J. D., Liu, D., Shi, Z., Harrison, R., Sun, Y., Xu, W., Lewis, A. C., Lee, J. D., Rickard, A. R., and Hamilton, J. F.: Strong anthropogenic control of secondary organic aerosol formation from isoprene in Beijing, Atmos. Chem. Phys., 20, 7531-7552, https://doi.org/10.5194/acp-20-7531-2020, 2020.

Budisulistiorini, S. H., Li, X., Bairai, S. T., Renfro, J., Liu, Y., Liu, Y. J., McKinney, K. A., Martin, S. T., McNeill, V. F., Pye, H. O. T., Nenes, A., Neff, M. E., Stone, E. A., Mueller, S., Knote, C., Shaw, S. L., Zhang, Z., Gold, A., and Surratt, J. D.: Examining the effects of anthropogenic emissions on isoprenederived secondary organic aerosol formation during the 2013 Southern Oxidant and Aerosol Study (SOAS) at the Look Rock, Tennessee ground site, Atmos. Chem. Phys., 15, 8871-8888, https://doi.org/10.5194/acp-15-8871-2015, 2015.

Chan, M. N., Surratt, J. D., Claeys, M., Edgerton, E. S., Tanner, R. L., Shaw, S. L., Zheng, M., Knipping, E. M., Eddingsaas, N. C., Wennberg, P. O., and Seinfeld, J. H.: Characterization and quantification of isoprene-derived epoxydiols in ambient aerosol in the southeastern United States, Environ. Sci. Technol., 44, 45904596, https://doi.org/10.1021/es100596b, 2010. 
Chan, M. N., Surratt, J. D., Chan, A. W. H., Schilling, K., Offenberg, J. H., Lewandowski, M., Edney, E. O., Kleindienst, T. E., Jaoui, M., Edgerton, E. S., Tanner, R. L., Shaw, S. L., Zheng, M., Knipping, E. M., and Seinfeld, J. H.: Influence of aerosol acidity on the chemical composition of secondary organic aerosol from $\beta$-caryophyllene, Atmos. Chem. Phys., 11, 1735-1751, https://doi.org/10.5194/acp-11-1735-2011, 2011.

Chen, Y., Zhang, Y., Lambe, A. T., Xu, R., Lei, Z., Olson, N. E., Zhang, Z., Szalkowski, T., Cui, T., Vizuete, W., Gold, A., Turpin, B. J., Ault, A. P., Chan, M. N., and Surratt, J. D.: Heterogeneous hydroxyl radical oxidation of isopreneepoxydiol-derived methyltetrol sulfates: plausible formation mechanisms of previously unexplained organosulfates in ambient fine aerosols, Environ. Sci. Technol. Lett., 7, 460-468, https://doi.org/10.1021/acs.estlett.0c00276, 2020.

Claeys, M., Wang, W., Vermeylen, R., Kourtchev, I., Chi, X., Farhat, Y., Surratt, J. D., Gómez-González, Y., Sciare, J., and Maenhaut, W.: Chemical characterisation of marine aerosol at Amsterdam Island during the austral summer of 2006-2007, J. Aerosol Sci., 41, 13=-22, https://doi.org/10.1016/j.jaerosci.2009.08.003, 2010.

Darer, A. I., Cole-Filipiak, N. C., O’Connor, A. E., and Elrod, M. J.: Formation and stability of atmospherically relevant isoprenederived organosulfates and organonitrates, Environ. Sci. Technol., 45, 1895-1902, https://doi.org/10.1021/es103797z, 2011.

DeRieux, W.-S. W., Li, Y., Lin, P., Laskin, J., Laskin, A., Bertram, A. K., Nizkorodov, S. A., and Shiraiwa, M.: Predicting the glass transition temperature and viscosity of secondary organic material using molecular composition, Atmos. Chem. Phys., 18, 6331-6351, https://doi.org/10.5194/acp-18-6331-2018, 2018.

Ding, A., Huang, X., Nie, W., Chi, X., Xu, Z., Zheng, L., Xu, Z., Xie, Y., Qi, X., Shen, Y., Sun, P., Wang, J., Wang, L., Sun, J., Yang, X.-Q., Qin, W., Zhang, X., Cheng, W., Liu, W., Pan, L., and Fu, C.: Significant reduction of $\mathrm{PM}_{2.5}$ in eastern China due to regional-scale emission control: evidence from SORPES in 2011-2018, Atmos. Chem. Phys., 19, 11791-11801, https://doi.org/10.5194/acp-19-11791-2019, 2019.

Ding, J., Zhao, P., Su, J., Dong, Q., Du, X., and Zhang, Y.: Aerosol $\mathrm{pH}$ and its driving factors in Beijing, Atmos. Chem. Phys., 19, 7939-7954, https://doi.org/10.5194/acp-19-7939-2019, 2019.

Estillore, A. D., Hettiyadura, A. P. S., Qin, Z., Leckrone, E., Wombacher, B., Humphry, T., Stone, E. A., and Grassian, V. H.: Water uptake and hygroscopic growth of organosulfate aerosol, Environ. Sci. Technol., 50, 4259-4268, https://doi.org/10.1021/acs.est.5b05014, 2016.

Fisseha, R., Dommen, J., Gutzwiller, L., Weingartner, E., Gysel, M., Emmenegger, C., Kalberer, M., and Baltensperger, U.: Seasonal and diurnal characteristics of water soluble inorganic compounds in the gas and aerosol phase in the Zurich area, Atmos. Chem. Phys., 6, 1895-1904, https://doi.org/10.5194/acp-6-18952006, 2006.

Fleming, L. T., Ali, N. N., Blair, S. L., Roveretto, M., George, C., and Nizkorodov, S. A.: Formation of light-absorbing organosulfates during evaporation of secondary organic material extracts in the presence of sulfuric acid, ACS Earth Space Chem., 3, 947957, https://doi.org/10.1021/acsearthspacechem.9b00036, 2019.

Fountoukis, C. and Nenes, A.: ISORROPIA II: a computationally efficient thermodynamic equilibrium model for $\mathrm{K}^{+}$$\mathrm{Ca}^{2+}-\mathrm{Mg}^{2+}-\mathrm{NH}_{4}^{+}-\mathrm{Na}^{+}-\mathrm{SO}_{4}^{2-}-\mathrm{NO}_{3}^{-}-\mathrm{Cl}^{-}-\mathrm{H}_{2} \mathrm{O}$ aerosols, At- mos. Chem. Phys., 7, 4639-4659, https://doi.org/10.5194/acp-74639-2007, 2007.

Froyd, K. D., Murphy, S. M., Murphy, D. M., de Gouw, J. A., Eddingsaas, N. C., and Wennberg, P. O.: Contribution of isoprene-derived organosulfates to free tropospheric aerosol mass, P. Natl. Acad. Sci. USA, 107, 21360-21365, https://doi.org/10.1073/pnas.1012561107, 2010.

Gómez-González, Y., Surratt, J. D., Cuyckens, F., Szmigielski, R., Vermeylen, R., Jaoui, M., Lewandowski, M., Offenberg, J. H., Kleindienst, T. E., Edney, E. O., Blockhuys, F., Van Alsenoy, C., Maenhaut, W., and Claeys, M.: Characterization of organosulfates from the photooxidation of isoprene and unsaturated fatty acids in ambient aerosol using liquid chromatography/(-) electrospray ionization mass spectrometry, J. Mass Spectrom., 43, 371-382, https://doi.org/10.1002/jms.1329, 2008.

Grgic, I., Dovzan, A., Bercic, G., and Hudnik, V.: The effect of atmospheric organic compounds on the Fe-catalyzed S(IV) autoxidation in aqueous solution, J. Atmos. Chem., 29, 315-337, https://doi.org/10.1023/a:1005918912994, 1998.

Griffith, S. M., Huang, X. H. H., Louie, P. K. K., and Yu, J. Z.: Characterizing the thermodynamic and chemical composition factors controlling $\mathrm{PM}_{2.5}$ nitrate: Insights gained from two years of online measurements in Hong Kong, Atmos. Environ., 122, 864875, https://doi.org/10.1016/j.atmosenv.2015.02.009, 2015.

Guenther, A., Hewitt, C. N., Erickson, D., Fall, R., Geron, C., Graedel, T., Harley, P., Klinger, L., Lerdau, M., McKay, W. A., Pierce, T., Scholes, B., Steinbrecher, R., Tallamraju, R., Taylor, J., and Zimmerman, P.: A global model of natural volatile organic compound emissions, J. Geophys. Res., 100, 8873-8892, https://doi.org/10.1029/94JD02950, 1995.

Guo, H., Xu, L., Bougiatioti, A., Cerully, K. M., Capps, S. L., Hite Jr., J. R., Carlton, A. G., Lee, S.-H., Bergin, M. H., Ng, N. L., Nenes, A., and Weber, R. J.: Fine-particle water and $\mathrm{pH}$ in the southeastern United States, Atmos. Chem. Phys., 15, 5211-5228, https://doi.org/10.5194/acp-15-5211-2015, 2015.

Guo, H., Sullivan, A. P., Campuzano-Jost, P., Schroder, J. C., LopezHilfiker, F. D., Dibb, J. E., Jimenez, J. L., Thornton, J. A., Brown, S. S., Nenes, A., and Weber, R. J.: Fine particle pH and the partitioning of nitric acid during winter in the northeastern United States, J. Geophys. Res.-Atmos., 121, 10355-10376, https://doi.org/10.1002/2016jd025311, 2016.

Hansen, A. M. K., Kristensen, K., Nguyen, Q. T., Zare, A., Cozzi, F., Nøjgaard, J. K., Skov, H., Brandt, J., Christensen, J. H., Ström, J., Tunved, P., Krejci, R., and Glasius, M.: Organosulfates and organic acids in Arctic aerosols: speciation, annual variation and concentration levels, Atmos. Chem. Phys., 14, 7807-7823, https://doi.org/10.5194/acp-14-7807-2014, 2014.

Hansen, A. M. K., Hong, J., Raatikainen, T., Kristensen, K., Ylisirniö, A., Virtanen, A., Petäjä, T., Glasius, M., and Prisle, N. L.: Hygroscopic properties and cloud condensation nuclei activation of limonene-derived organosulfates and their mixtures with ammonium sulfate, Atmos. Chem. Phys., 15, 14071-14089, https://doi.org/10.5194/acp-15-14071-2015, 2015.

Hatch, L. E., Creamean, J. M., Ault, A. P., Surratt, J. D., Chan, M. N., Seinfeld, J. H., Edgerton, E. S., Su, Y., and Prather, K. A.: Measurements of isoprene-derived organosulfates in ambient aerosols by aerosol time-of-flight mass spectrometry-part 2: temporal variability and formation mechanisms, Environ. Sci. Technol., 45, 8648-8655, https://doi.org/10.1021/es2011836, 2011. 
Hawkins, L. N., Russell, L. M., Covert, D. S., Quinn, P. K., and Bates, T. S.: Carboxylic acids, sulfates, and organosulfates in processed continental organic aerosol over the southeast Pacific Ocean during VOCALS-REx 2008, J. Geophys. Res., 115, D13201, https://doi.org/10.1029/2009jd013276, 2010.

He, Q. F., Ding, X., Wang, X. M., Yu, J. Z., Fu, X. X., Liu, T. Y., Zhang, Z., Xue, J., Chen, D. H., Zhong, L. J., and Donahue, N. M.: Organosulfates from pinene and isoprene over the Pearl River Delta, South China: seasonal variation and implication in formation mechanisms, Environ. Sci. Technol., 48, 9236-9245, https://doi.org/10.1021/es501299v, 2014.

He, Q. F., Ding, X., Fu, X. X., Zhang, Y. Q., Wang, J. Q., Liu, Y. X., Tang, M. J., Wang, X. M., and Rudich, Y.: Secondary organic aerosol formation from isoprene epoxides in the Pearl River Delta, South China: IEPOX- and HMMLderived tracers, J. Geophys. Res.-Atmos., 123, 6999-7012, https://doi.org/10.1029/2017jd028242, 2018.

Hennigan, C. J., Izumi, J., Sullivan, A. P., Weber, R. J., and Nenes, A.: A critical evaluation of proxy methods used to estimate the acidity of atmospheric particles, Atmos. Chem. Phys., 15, 27752790, https://doi.org/10.5194/acp-15-2775-2015, 2015.

Herrmann, H.: Kinetics of aqueous phase reactions relevant for atmospheric chemistry, Chem. Rev., 103, 4691-4716, https://doi.org/10.1021/cr020658q, 2003.

Hettiyadura, A. P. S., Stone, E. A., Kundu, S., Baker, Z., Geddes, E., Richards, K., and Humphry, T.: Determination of atmospheric organosulfates using HILIC chromatography with MS detection, Atmos. Meas. Tech., 8, 2347-2358, https://doi.org/10.5194/amt8-2347-2015, 2015.

Hettiyadura, A. P. S., Jayarathne, T., Baumann, K., Goldstein, A. H., de Gouw, J. A., Koss, A., Keutsch, F. N., Skog, K., and Stone, E. A.: Qualitative and quantitative analysis of atmospheric organosulfates in Centreville, Alabama, Atmos. Chem. Phys., 17, 1343-1359, https://doi.org/10.5194/acp-17-1343-2017, 2017.

Hettiyadura, A. P. S., Al-Naiema, I. M., Hughes, D. D., Fang, T., and Stone, E. A.: Organosulfates in Atlanta, Georgia: anthropogenic influences on biogenic secondary organic aerosol formation, Atmos. Chem. Phys., 19, 3191-3206, https://doi.org/10.5194/acp19-3191-2019, 2019.

Hoffmann, T., Huang, R. J., and Kalberer, M.: Atmospheric analytical chemistry, Anal. Chem., 83, 4649-4664, https://doi.org/10.1021/ac2010718, 2011.

Huang, L., Coddens, E. M., and Grassian, V. H.: Formation of organosulfur compounds from aqueous phase reactions of S(IV) with methacrolein and methyl vinyl ketone in the presence of transition metal ions, ACS Earth Space Chem., 3, 1749-1755, https://doi.org/10.1021/acsearthspacechem.9b00173, 2019.

Huang, L., Liu, T., and Grassian, V. H.: Radical-initiated formation of aromatic organosulfates and sulfonates in the aqueous phase, Environ. Sci. Technol., 54, 11857-11864, https://doi.org/10.1021/acs.est.0c05644, 2020.

Huang, R.-J., Zhang, Y., Bozzetti, C., Ho, K.-F., Cao, J.-J., Han, Y., Daellenbach, K. R., Slowik, J. G., Platt, S. M., Canonaco, F., Zotter, P., Wolf, R., Pieber, S. M., Bruns, E. A., Crippa, M., Ciarelli, G., Piazzalunga, A., Schwikowski, M., Abbaszade, G., SchnelleKreis, J., Zimmermann, R., An, Z., Szidat, S., Baltensperger, U., El Haddad, I., and Prevot, A. S. H.: High secondary aerosol contribution to particulate pollution during haze events in China, Nature, 514, 218-222, https://doi.org/10.1038/nature13774, 2014.
Huang, R.-J., Cao, J., Chen, Y., Yang, L., Shen, J., You, Q., Wang, K., Lin, C., Xu, W., Gao, B., Li, Y., Chen, Q., Hoffmann, T., O'Dowd, C. D., Bilde, M., and Glasius, M.: Organosulfates in atmospheric aerosol: synthesis and quantitative analysis of $\mathrm{PM}_{2.5}$ from Xi' an, northwestern China, Atmos. Meas. Tech., 11, 34473456, https://doi.org/10.5194/amt-11-3447-2018, 2018.

Iinuma, Y., Mueller, C., Berndt, T., Boege, O., Claeys, M., and Herrmann, H.: Evidence for the existence of organosulfates from $\beta$ pinene ozonolysis in ambient secondary organic aerosol, Environ. Sci. Technol., 41, 6678-6683, 2007a.

Iinuma, Y., Mueller, C., Boege, O., Gnauk, T., and Herrmann, H.: The formation of organic sulfate esters in the limonene ozonolysis secondary organic aerosol (SOA) under acidic conditions, Atmos. Environ., 41, 5571-5583, https://doi.org/10.1016/j.atmosenv.2007.03.007, 2007b.

Iinuma, Y., Boege, O., Kahnt, A., and Herrmann, H.: Laboratory chamber studies on the formation of organosulfates from reactive uptake of monoterpene oxides, Phys. Chem. Chem. Phys., 11, 7985-7997, https://doi.org/10.1039/b904025k, 2009.

Jiang, P.-Y., Katsumura, Y., Domae, M., Ishikawa, K., Ishigure, K., and Yoshida, Y.: Pulse radiolysis study of concentrated sulfuric acid solutions. Formation mechanism, yield and reactivity of sulfate radicals, J. Chem. Soc. Faraday T., 88, 3319-3322, https://doi.org/10.1039/ft9928801653, 1992.

Jimenez, J. L., Canagaratna, M. R., Donahue, N. M., Prevot, A. S. H., Zhang, Q., Kroll, J. H., DeCarlo, P. F., Allan, J. D., Coe, H., Ng, N. L., Aiken, A. C., Docherty, K. S., Ulbrich, I. M., Grieshop, A. P., Robinson, A. L., Duplissy, J., Smith, J. D., Wilson, K. R., Lanz, V. A., Hueglin, C., Sun, Y. L., Tian, J., Laaksonen, A., Raatikainen, T., Rautiainen, J., Vaattovaara, P., Ehn, M., Kulmala, M., Tomlinson, J. M., Collins, D. R., Cubison, M. J., Dunlea, E. J., Huffman, J. A., Onasch, T. B., Alfarra, M. R., Williams, P. I., Bower, K., Kondo, Y., Schneider, J., Drewnick, F., Borrmann, S., Weimer, S., Demerjian, K., Salcedo, D., Cottrell, L., Griffin, R., Takami, A., Miyoshi, T., Hatakeyama, S., Shimono, A., Sun, J. Y., Zhang, Y. M., Dzepina, K., Kimmel, J. R., Sueper, D., Jayne, J. T., Herndon, S. C., Trimborn, A. M., Williams, L. R., Wood, E. C., Middlebrook, A. M., Kolb, C. E., Baltensperger, U., and Worsnop, D. R.: Evolution of organic aerosols in the atmosphere, Science, 326, 1525-1529, https://doi.org/10.1126/science.1180353, 2009.

Johnston, M. V. and Kerecman, D. E.: Molecular characterization of atmospheric organic aerosol by mass spectrometry, Annu. Rev. Anal. Chem., 12, 247-274, https://doi.org/10.1146/annurevanchem-061516-045135, 2019.

Kourtchev, I., Godoi, R. H. M., Connors, S., Levine, J. G., Archibald, A. T., Godoi, A. F. L., Paralovo, S. L., Barbosa, C. G. G., Souza, R. A. F., Manzi, A. O., Seco, R., Sjostedt, S., Park, J.H., Guenther, A., Kim, S., Smith, J., Martin, S. T., and Kalberer, M.: Molecular composition of organic aerosols in central Amazonia: an ultra-high-resolution mass spectrometry study, Atmos. Chem. Phys., 16, 11899-11913, https://doi.org/10.5194/acp-1611899-2016, 2016.

Kristensen, K. and Glasius, M.: Organosulfates and oxidation products from biogenic hydrocarbons in fine aerosols from a forest in North West Europe during spring, Atmos. Environ., 45, 45464556, https://doi.org/10.1016/j.atmosenv.2011.05.063, 2011.

Kundu, S., Quraishi, T. A., Yu, G., Suarez, C., Keutsch, F. N., and Stone, E. A.: Evidence and quantitation of aromatic 
organosulfates in ambient aerosols in Lahore, Pakistan, Atmos. Chem. Phys., 13, 4865-4875, https://doi.org/10.5194/acp-134865-2013, 2013.

Le Breton, M., Wang, Y., Hallquist, Å. M., Pathak, R. K., Zheng, J., Yang, Y., Shang, D., Glasius, M., Bannan, T. J., Liu, Q., Chan, C. K., Percival, C. J., Zhu, W., Lou, S., Topping, D., Wang, Y., Yu, J., Lu, K., Guo, S., Hu, M., and Hallquist, M.: Online gasand particle-phase measurements of organosulfates, organosulfonates and nitrooxy organosulfates in Beijing utilizing a FIGAERO ToF-CIMS, Atmos. Chem. Phys., 18, 10355-10371, https://doi.org/10.5194/acp-18-10355-2018, 2018.

Lewandowski, M., Jaoui, M., Offenberg, J. H., Krug, J. D., and Kleindienst, T. E.: Atmospheric oxidation of isoprene and 1,3butadiene: influence of aerosol acidity and relative humidity on secondary organic aerosol, Atmos. Chem. Phys., 15, 3773-3783, https://doi.org/10.5194/acp-15-3773-2015, 2015.

Liao, J., Froyd, K. D., Murphy, D. M., Keutsch, F. N., Yu, G., Wennberg, P. O., St. Clair, J. M., Crounse, J. D., Wisthaler, A., Mikoviny, T., Jimenez, J. L., Campuzano-Jost, P., Day, D. A., Hu, W., Ryerson, T. B., Pollack, I. B., Peischl, J., Anderson, B. E., Ziemba, L. D., Blake, D. R., Meinardi, S., and Diskin, G.: Airborne measurements of organosulfates over the continental US, J. Geophys. Res.-Atmos., 120, 2990-3005, https://doi.org/10.1002/2014jd022378, 2015.

Lin, P., Yu, J. Z., Engling, G., and Kalberer, M.: Organosulfates in humic-like substance fraction isolated from aerosols at seven locations in East Asia: a study by ultra-high-resolution mass spectrometry, Environ. Sci. Technol., 46, 13118-13127, https://doi.org/10.1021/es303570v, 2012.

Lin, Y. H., Zhang, Z., Docherty, K. S., Zhang, H., Budisulistiorini, S. H., Rubitschun, C. L., Shaw, S. L., Knipping, E. M., Edgerton, E. S., Kleindienst, T. E., Gold, A., and Surratt, J. D.: Isoprene epoxydiols as precursors to secondary organic aerosol formation: acid-catalyzed reactive uptake studies with authentic compounds, Environ. Sci. Technol., 46, 250-258, https://doi.org/10.1021/es202554c, 2012.

Lin, Y. H., Zhang, H., Pye, H. O., Zhang, Z., Marth, W. J., Park, S., Arashiro, M., Cui, T., Budisulistiorini, S. H., Sexton, K. G., Vizuete, W., Xie, Y., Luecken, D. J., Piletic, I. R., Edney, E. O., Bartolotti, L. J., Gold, A., and Surratt, J. D.: Epoxide as a precursor to secondary organic aerosol formation from isoprene photooxidation in the presence of nitrogen oxides, P. Natl. Acad. Sci. USA, 110, 6718-6723, https://doi.org/10.1073/pnas.1221150110, 2013.

Liu, M. X., Song, Y., Zhou, T., Xu, Z. Y., Yan, C. Q., Zheng, M., Wu, Z. J., Hu, M., Wu, Y. S., and Zhu, T.: Fine particle pH during severe haze episodes in northern China, Geophys. Res. Lett., 44, 5213-5221, https://doi.org/10.1002/2017g1073210, 2017.

Liu, Y. and Wang, T.: Worsening urban ozone pollution in China from 2013 to 2017 - Part 2: The effects of emission changes and implications for multi-pollutant control, Atmos. Chem. Phys., 20, 6323-6337, https://doi.org/10.5194/acp-206323-2020, 2020.

Lukács, H., Gelencsér, A., Hoffer, A., Kiss, G., Horváth, K., and Hartyáni, Z.: Quantitative assessment of organosulfates in sizesegregated rural fine aerosol, Atmos. Chem. Phys., 9, 231-238, https://doi.org/10.5194/acp-9-231-2009, 2009.

Ma, Y., Xu, X., Song, W., Geng, F., and Wang, L.: Seasonal and diurnal variations of particulate organosulfates in urban Shanghai, China, Atmos. Environ., 85, 152-160, https://doi.org/10.1016/j.atmosenv.2013.12.017, 2014.

Mahowald, N.: Aerosol indirect effect on biogeochemical cycles and climate, Science, 334, 794-796, https://doi.org/10.1126/science.1207374, 2011.

McNeill, V. F., Woo, J. L., Kim, D. D., Schwier, A. N., Wannell, N. J., Sumner, A. J., and Barakat, J. M.: Aqueous-phase secondary organic aerosol and organosulfate formation in atmospheric aerosols: a modeling study, Environ. Sci. Technol., 46, 8075-8081, https://doi.org/10.1021/es3002986, 2012.

Meade, L. E., Riva, M., Blomberg, M. Z., Brock, A. K., Qualters, E. M., Siejack, R. A., Ramakrishnan, K., Surratt, J. D., and Kautzman, K. E.: Seasonal variations of fine particulate organosulfates derived from biogenic and anthropogenic hydrocarbons in the mid-Atlantic United States, Atmos. Environ., 145, 405-414, https://doi.org/10.1016/j.atmosenv.2016.09.028, 2016.

Nah, T., Guo, H., Sullivan, A. P., Chen, Y., Tanner, D. J., Nenes, A., Russell, A., Ng, N. L., Huey, L. G., and Weber, R. J.: Characterization of aerosol composition, aerosol acidity, and organic acid partitioning at an agriculturally intensive rural southeastern US site, Atmos. Chem. Phys., 18, 11471-11491, https://doi.org/10.5194/acp-18-11471-2018, 2018.

Nestorowicz, K., Jaoui, M., Rudzinski, K. J., Lewandowski, M., Kleindienst, T. E., Spólnik, G., Danikiewicz, W., and Szmigielski, R.: Chemical composition of isoprene SOA under acidic and non-acidic conditions: effect of relative humidity, Atmos. Chem. Phys., 18, 18101-18121, https://doi.org/10.5194/acp-18-181012018, 2018.

Nguyen, Q. T., Christensen, M. K., Cozzi, F., Zare, A., Hansen, A. M. K., Kristensen, K., Tulinius, T. E., Madsen, H. H., Christensen, J. H., Brandt, J., Massling, A., Nøjgaard, J. K., and Glasius, M.: Understanding the anthropogenic influence on formation of biogenic secondary organic aerosols in Denmark via analysis of organosulfates and related oxidation products, Atmos. Chem. Phys., 14, 8961-8981, https://doi.org/10.5194/acp14-8961-2014, 2014.

Nguyen, T. B., Lee, P. B., Updyke, K. M., Bones, D. L., Laskin, J., Laskin, A., and Nizkorodov, S. A.: Formation of nitrogen- and sulfur-containing light-absorbing compounds accelerated by evaporation of water from secondary organic aerosols, J. Geophys. Res.-Atmos., 117, D01207, https://doi.org/10.1029/2011jd016944, 2012.

Nguyen, T. B., Bates, K. H., Crounse, J. D., Schwantes, R. H., Zhang, X., Kjaergaard, H. G., Surratt, J. D., Lin, P., Laskin, A., Seinfeld, J. H., and Wennberg, P. O.: Mechanism of the hydroxyl radical oxidation of methacryloyl peroxynitrate (MPAN) and its pathway toward secondary organic aerosol formation in the atmosphere, Phys. Chem. Chem. Phys., 17, 17914-17926, https://doi.org/10.1039/c5cp02001h, 2015.

Nozière, B., Ekström, S., Alsberg, T., and Holmström, S.: Radical-initiated formation of organosulfates and surfactants in atmospheric aerosols, Geophys. Res. Lett., 37, L05806, https://doi.org/10.1029/2009g1041683, 2010.

Nozière, B., Kalberer, M., Claeys, M., Allan, J., D’Anna, B., Decesari, S., Finessi, E., Glasius, M., Grgic, I., Hamilton, J. F., Hoffmann, T., Iinuma, Y., Jaoui, M., Kahno, A., Kampf, C. J., Kourtchev, I., Maenhaut, W., Marsden, N., Saarikoski, S., Schnelle-Kreis, J., Surratt, J. D., Szidat, S., Szmigielski, R., and Wisthaler, A.: The molecular identification of organic com- 
pounds in the atmosphere: state of the art and challenges, Chem. Rev., 115, 3919-3983, https://doi.org/10.1021/cr5003485, 2015. Olson, C. N., Galloway, M. M., Yu, G., Hedman, C. J., Lockett, M. R., Yoon, T., Stone, E. A., Smith, L. M., and Keutsch, F. N.: Hydroxycarboxylic acid-derived organosulfates: synthesis, stability, and quantification in ambient aerosol, Environ. Sci. Technol., 45, 6468-6474, https://doi.org/10.1021/es201039p, 2011.

Olson, N. E., Lei, Z. Y., Craig, R. L., Zhang, Y., Chen, Y. Z., Lambe, A. T., Zhang, Z. F., Gold, A., Surratt, J. D., and Ault, A. P.: Reactive uptake of isoprene epoxydiols increases the viscosity of the core of phase-separated aerosol particles, ACS Earth Space Chem., 3, 1402-1414, https://doi.org/10.1021/acsearthspacechem.9b00138, 2019.

Passananti, M., Kong, L., Shang, J., Dupart, Y., Perrier, S., Chen, J., Donaldson, D. J., and George, C.: Organosulfate formation through the heterogeneous reaction of sulfur dioxide with unsaturated fatty acids and long-chain alkenes, Angew. Chem. Int. Ed. Engl., 55, 10336-10339, https://doi.org/10.1002/anie.201605266, 2016.

Pye, H. O. T., Pinder, R. W., Piletic, I. R., Xie, Y., Capps, S. L., Lin, Y. H., Surratt, J. D., Zhang, Z. F., Gold, A., Luecken, D. J., Hutzell, W. T., Jaoui, M., Offenberg, J. H., Kleindienst, T. E., Lewandowski, M., and Edney, E. O.: Epoxide pathways improve model predictions of isoprene markers and reveal key role of acidity in aerosol formation, Environ. Sci. Technol., 47, 1105611064, https://doi.org/10.1021/es402106h, 2013.

Ramanathan, V., Crutzen, P. J., Lelieveld, J., Mitra, A. P., Althausen, D., Anderson, J., Andreae, M. O., Cantrell, W., Cass, G. R., Chung, C. E., Clarke, A. D., Coakley, J. A., Collins, W. D., Conant, W. C., Dulac, F., Heintzenberg, J., Heymsfield, A. J., Holben, B., Howell, S., Hudson, J., Jayaraman, A., Kiehl, J. T., Krishnamurti, T. N., Lubin, D., McFarquhar, G., Novakov, T., Ogren, J. A., Podgorny, I. A., Prather, K., Priestley, K., Prospero, J. M., Quinn, P. K., Rajeev, K., Rasch, P., Rupert, S., Sadourny, R., Satheesh, S. K., Shaw, G. E., Sheridan, P., and Valero, F. P. J.: Indian Ocean Experiment: an integrated analysis of the climate forcing and effects of the great Indo-Asian haze, J. Geophys. Res.-Atmos., 106, 28371-28398, https://doi.org/10.1029/2001jd900133, 2001.

Rattanavaraha, W., Chu, K., Budisulistiorini, S. H., Riva, M., Lin, Y.-H., Edgerton, E. S., Baumann, K., Shaw, S. L., Guo, H., King, L., Weber, R. J., Neff, M. E., Stone, E. A., Offenberg, J. H., Zhang, Z., Gold, A., and Surratt, J. D.: Assessing the impact of anthropogenic pollution on isoprene-derived secondary organic aerosol formation in $\mathrm{PM}_{2.5}$ collected from the Birmingham, Alabama, ground site during the 2013 Southern Oxidant and Aerosol Study, Atmos. Chem. Phys., 16, 4897-4914, https://doi.org/10.5194/acp-16-4897-2016, 2016.

Riva, M., Tomaz, S., Cui, T., Lin, Y. H., Perraudin, E., Gold, A., Stone, E. A., Villenave, E., and Surratt, J. D.: Evidence for an unrecognized secondary anthropogenic source of organosulfates and sulfonates: gas-phase oxidation of polycyclic aromatic hydrocarbons in the presence of sulfate aerosol, Environ. Sci. Technol., 49, 6654-6664, https://doi.org/10.1021/acs.est.5b00836, 2015.

Riva, M., Budisulistiorini, S. H., Zhang, Z. F., Gold, A., and Surratt, J. D.: Chemical characterization of secondary organic aerosol constituents from isoprene ozonolysis in the presence of acidic aerosol, Atmos. Environ., 130, 5-13, https://doi.org/10.1016/j.atmosenv.2015.06.027, 2016a.

Riva, M., Da Silva Barbosa, T., Lin, Y.-H., Stone, E. A., Gold, A., and Surratt, J. D.: Chemical characterization of organosulfates in secondary organic aerosol derived from the photooxidation of alkanes, Atmos. Chem. Phys., 16, 11001-11018, https://doi.org/10.5194/acp-16-11001-2016, 2016b.

Riva, M., Chen, Y., Zhang, Y., Lei, Z., Olson, N. E., Boyer, H. C., Narayan, S., Yee, L. D., Green, H. S., Cui, T., Zhang, Z., Baumann, K., Fort, M., Edgerton, E., Budisulistiorini, S. H., Rose, C. A., Ribeiro, I. O., RL, E. O., Dos Santos, E. O., Machado, C. M. D., Szopa, S., Zhao, Y., Alves, E. G., de Sa, S. S., Hu, W., Knipping, E. M., Shaw, S. L., Duvoisin Junior, S., de Souza, R. A. F., Palm, B. B., Jimenez, J. L., Glasius, M., Goldstein, A. H., Pye, H. O. T., Gold, A., Turpin, B. J., Vizuete, W., Martin, S. T., Thornton, J. A., Dutcher, C. S., Ault, A. P., and Surratt, J. D.: Increasing isoprene epoxydiol-to-inorganic sulfate aerosol ratio results in extensive conversion of inorganic sulfate to organosulfur forms: implications for aerosol physicochemical properties, Environ. Sci. Technol., 53, 8682-8694, https://doi.org/10.1021/acs.est.9b01019, 2019.

Schindelka, J., Iinuma, Y., Hoffmann, D., and Herrmann, H.: Sulfate radical-initiated formation of isoprene-derived organosulfates in atmospheric aerosols, Faraday Discuss., 165, 237-259, https://doi.org/10.1039/c3fd00042g, 2013.

Shakya, K. M. and Peltier, R. E.: Investigating missing sources of sulfur at Fairbanks, Alaska, Environ. Sci. Technol., 47, 93329338, https://doi.org/10.1021/es402020b, 2013.

Shakya, K. M. and Peltier, R. E.: Non-sulfate sulfur in fine aerosols across the United States: Insight for organosulfate prevalence, Atmos. Environ., 100, 159-166, https://doi.org/10.1016/j.atmosenv.2014.10.058, 2015.

Shalamzari, M. S., Ryabtsova, O., Kahnt, A., Vermeylen, R., Herent, M. F., Quetin-Leclercq, J., Van der Veken, P., Maenhaut, W., and Claeys, M.: Mass spectrometric characterization of organosulfates related to secondary organic aerosol from isoprene, Rapid Commun. Mass Sp., 27, 784-794, https://doi.org/10.1002/rcm.6511, 2013.

Shang, J., Passananti, M., Dupart, Y., Ciuraru, R., Tinel, L., Rossignol, S., Perrier, S., Zhu, T., and George, C.: $\mathrm{SO}_{2}$ uptake on oleic acid: a new formation pathway of organosulfur compounds in the atmosphere, Environ. Sci. Technol. Lett., 3, 67-72, https://doi.org/10.1021/acs.estlett.6b00006, 2016.

Shi, G. L., Xu, J., Peng, X., Xiao, Z. M., Chen, K., Tian, Y. Z., Guan, X. B., Feng, Y. C., Yu, H. F., Nenes, A., and Russell, A. G.: aerosols in a polluted atmosphere: source contributions to highly acidic aerosol, Environ. Sci. Technol., 51, 4289-4296, https://doi.org/10.1021/acs.est.6b05736, 2017.

Shiraiwa, M., Ammann, M., Koop, T., and Pöschl, U.: Gas uptake and chemical aging of semisolid organic aerosol particles, P. Natl. Acad. Sci. USA, 108, 11003-11008, https://doi.org/10.1073/pnas.1103045108, 2011.

Shrivastava, M., Cappa, C. D., Fan, J. W., Goldstein, A. H., Guenther, A. B., Jimenez, J. L., Kuang, C., Laskin, A., Martin, S. T., Ng, N. L., Petaja, T., Pierce, J. R., Rasch, P. J., Roldin, P., Seinfeld, J. H., Shilling, J., Smith, J. N., Thornton, J. A., Volkamer, R., Wang, J., Worsnop, D. R., Zaveri, R. A., Zelenyuk, A., and Zhang, Q.: Recent advances in understanding secondary organic 
aerosol: Implications for global climate forcing, Rev. Geophys., 55, 509-559, 2017.

Song, S., Nenes, A., Gao, M., Zhang, Y., Liu, P., Shao, J., Ye, D., Xu, W., Lei, L., Sun, Y., Liu, B., Wang, S., and McElroy, M. B.: Thermodynamic modeling suggests declines in water uptake and acidity of inorganic aerosols in Beijing winter haze events during 2014/2015-2018/2019, Environ. Sci. Technol. Lett., 6, 752-760, https://doi.org/10.1021/acs.estlett.9b00621, 2019.

Staudt, S., Kundu, S., Lehmler, H. J., He, X., Cui, T., Lin, Y. H., Kristensen, K., Glasius, M., Zhang, X., Weber, R. J., Surratt, J. D., and Stone, E. A.: Aromatic organosulfates in atmospheric aerosols: synthesis, characterization, and abundance, Atmos. Environ., 94, 366-373, https://doi.org/10.1016/j.atmosenv.2014.05.049, 2014.

Stone, E. A., Yang, L., Yu, L. E., and Rupakheti, M.: Characterization of organosulfates in atmospheric aerosols at Four Asian locations, Atmos. Environ., 47, 323-329, https://doi.org/10.1016/j.atmosenv.2011.10.058, 2012.

Surratt, J. D., Kroll, J. H., Kleindienst, T. E., Edney, E. O., Claeys, M., Sorooshian, A., Ng, N. L., Offenberg, J. H., Lewandowski, M., Jaoui, M., Flagan, R. C., and Seinfeld, J. H.: Evidence for organosulfates in secondary organic aerosol, Environ. Sci. Technol., 41, 517-527, https://doi.org/10.1021/es062081q, 2007a.

Surratt, J. D., Lewandowski, M., Offenberg, J. H., Jaoui, M., Kleindienst, T. E., Edney, E. O., and Seinfeld, J. H.: Effect of acidity on secondary organic aerosol formation from isoprene, Environ. Sci. Technol., 41, 5363-5369, https://doi.org/10.1021/es0704176, 2007b.

Surratt, J. D., Gómez-González, Y., Chan, A. W. H., Vermeylen, R., Shahgholi, M., Kleindienst, T. E., Edney, E. O., Offenberg, J. H., Lewandowski, M., Jaoui, M., Maenhaut, W., Claeys, M., Richard C. Flagan, and Seinfeld, J. H.: Organosulfate formation in biogenic secondary organic aerosol, J. Phys. Chem. A, 36, 83458378, 2008.

Surratt, J. D., Chan, A. W., Eddingsaas, N. C., Chan, M., Loza, C. L., Kwan, A. J., Hersey, S. P., Flagan, R. C., Wennberg, P. O., and Seinfeld, J. H.: Reactive intermediates revealed in secondary organic aerosol formation from isoprene, P. Natl. Acad. Sci. USA, 107, 6640-6645, https://doi.org/10.1073/pnas.0911114107, 2010.

Tao, J., Zhang, L., Cao, J., and Zhang, R.: A review of current knowledge concerning $\mathrm{PM}_{2.5}$ chemical composition, aerosol optical properties and their relationships across China, Atmos. Chem. Phys., 17, 9485-9518, https://doi.org/10.5194/acp-179485-2017, 2017.

Tao, S., Lu, X., Levac, N., Bateman, A. P., Nguyen, T. B., Bones, D. L., Nizkorodov, S. A., Laskin, J., Laskin, A., and Yang, X.: Molecular characterization of organosulfates in organic aerosols from Shanghai and Los Angeles urban areas by nanospray-desorption electrospray ionization high-resolution mass spectrometry, Environ. Sci. Technol., 48, 10993-11001, https://doi.org/10.1021/es5024674, 2014.

Tolocka, M. P. and Turpin, B.: Contribution of organosulfur compounds to organic aerosol mass, Environ. Sci. Technol., 46, 7978-7983, https://doi.org/10.1021/es300651v, 2012.

Wach, P., Spolnik, G., Rudzinski, K. J., Skotak, K., Claeys, M., Danikiewicz, W., and Szmigielski, R.: Radical oxidation of methyl vinyl ketone and methacrolein in aqueous droplets: characterization of organosulfates and atmospheric implications, Chemosphere, 214, 1-9, https://doi.org/10.1016/j.chemosphere.2018.09.026, 2019.

Wang, H. C., Chen, X. R., Lu, K. D., Hu, R. Z., Li, Z. Y., Wang, H. L., Ma, X. F., Yang, X. P., Chen, S. Y., Dong, H. B., Liu, Y., Fang, X., Zeng, L. M., Hu, M., and Zhang, Y. H.: $\mathrm{NO}_{3}$ and $\mathrm{N}_{2} \mathrm{O}_{5}$ chemistry at a suburban site during the EXPLORE-YRD campaign in 2018, Atmos. Environ., 224, 117180, https://doi.org/10.1016/j.atmosenv.2019.117180, 2020.

Wang, H. L., Qiao, L. P., Lou, S. R., Zhou, M., Ding, A. J., Huang, H. Y., Chen, J. M., Wang, Q., Tao, S. K., Chen, C. H., Li, L., and Huang, C.: Chemical composition of $\mathrm{PM}_{2.5}$ and meteorological impact among three years in urban Shanghai, China, J. Clean Prod., 112, 1302-1311, https://doi.org/10.1016/j.jclepro.2015.04.099, 2016.

Wang, J. J., Lu, X. M., Yan, Y. T., Zhou, L. G., and Ma, W. C.: Spatiotemporal characteristics of $\mathrm{PM}_{2.5}$ concentration in the Yangtze River Delta urban agglomeration, China on the application of big data and wavelet analysis, Sci. Total Environ., 724, 138134, https://doi.org/10.1016/j.scitotenv.2020.138134, 2020.

Wang, K., Zhang, Y., Huang, R. J., Wang, M., Ni, H., Kampf, C. J., Cheng, Y., Bilde, M., Glasius, M., and Hoffmann, T. Molecular characterization and source identification of atmospheric particulate organosulfates using ultrahigh resolution mass spectrometry, Environ. Sci. Technol., 53, 6192-6202, https://doi.org/10.1021/acs.est.9b02628, 2019.

Wang, S. Y., Zhou, S. M., Tao, Y., Tsui, W. G., Ye, J. H., Yu, J. Z., Murphy, J. G., McNeill, V. F., Abbatt, J. P. D., and Chan, A. W. H.: Organic peroxides and sulfur dioxide in aerosol: source of particulate sulfate, Environ. Sci. Technol., 53, 10695-10704, https://doi.org/10.1021/acs.est.9b02591, 2019.

Wang, X. K., Rossignol, S., Ma, Y., Yao, L., Wang, M. Y., Chen, J. M., George, C., and Wang, L.: Molecular characterization of atmospheric particulate organosulfates in three megacities at the middle and lower reaches of the Yangtze River, Atmos. Chem. Phys., 16, 2285-2298, https://doi.org/10.5194/acp16-2285-2016, 2016.

Wang, Y., Ren, J., Huang, X. H. H., Tong, R., and Yu, J. Z.: Synthesis of four monoterpene-derived organosulfates and their quantification in atmospheric aerosol samples, Environ. Sci. Technol., 51, 6791-6801, https://doi.org/10.1021/acs.est.7b01179, 2017.

Wang, Y., Hu, M., Guo, S., Wang, Y., Zheng, J., Yang, Y., Zhu, W., Tang, R., Li, X., Liu, Y., Le Breton, M., Du, Z., Shang, D., Wu, Y., Wu, Z., Song, Y., Lou, S., Hallquist, M., and Yu, J.: The secondary formation of organosulfates under interactions between biogenic emissions and anthropogenic pollutants in summer in Beijing, Atmos. Chem. Phys., 18, 10693-10713, https://doi.org/10.5194/acp-18-10693-2018, 2018.

Wen, L., Xue, L., Wang, X., Xu, C., Chen, T., Yang, L., Wang, T., Zhang, Q., and Wang, W.: Summertime fine particulate nitrate pollution in the North China Plain: increasing trends, formation mechanisms and implications for control policy, Atmos. Chem. Phys., 18, 11261-11275, https://doi.org/10.5194/acp-18-112612018, 2018.

Worton, D. R., Surratt, J. D., Lafranchi, B. W., Chan, A. W., Zhao, Y., Weber, R. J., Park, J. H., Gilman, J. B., de Gouw, J., Park, C., Schade, G., Beaver, M., Clair, J. M., Crounse, J., Wennberg, P., Wolfe, G. M., Harrold, S., Thornton, J. A., Farmer, D. K., Docherty, K. S., Cubison, M. J., Jimenez, J. L., Frossard, A. A., Russell, L. M., Kristensen, K., Glasius, M., Mao, J., Ren, X., 
Brune, W., Browne, E. C., Pusede, S. E., Cohen, R. C., Seinfeld, J. H., and Goldstein, A. H.: Observational insights into aerosol formation from isoprene, Environ. Sci. Technol., 47, 1140311413, https://doi.org/10.1021/es4011064, 2013.

Yao, M., Zhao, Y., Hu, M., Huang, D., Wang, Y., Yu, J. Z., and Yan, N.: Multiphase reactions between secondary organic aerosol and sulfur dioxide: kinetics and contributions to sulfate formation and aerosol aging, Environ. Sci. Technol. Lett., 6, 768-774, https://doi.org/10.1021/acs.estlett.9b00657, 2019.

Yassine, M. M., Dabek-Zlotorzynska, E., Harir, M., and SchmittKopplin, P.: Identification of weak and strong organic acids in atmospheric aerosols by capillary electrophoresis/mass spectrometry and ultra-high-resolution fourier transform ion cyclotron resonance mass spectrometry, Anal. Chem., 84, 6586-6594, https://doi.org/10.1021/ac300798g, 2012.

Zhang, H., Worton, D. R., Lewandowski, M., Ortega, J., Rubitschun, C. L., Park, J. H., Kristensen, K., Campuzano-Jost, P., Day, D. A., Jimenez, J. L., Jaoui, M., Offenberg, J. H., Kleindienst, T. E., Gilman, J., Kuster, W. C., de Gouw, J., Park, C., Schade, G. W., Frossard, A. A., Russell, L., Kaser, L., Jud, W., Hansel, A., Cappellin, L., Karl, T., Glasius, M., Guenther, A., Goldstein, A. H., Seinfeld, J. H., Gold, A., Kamens, R. M., and Surratt, J. D.: Organosulfates as tracers for secondary organic aerosol (SOA) formation from 2-methyl-3-buten-2-ol (MBO) in the atmosphere, Environ. Sci. Technol., 46, 94379446, https://doi.org/10.1021/es301648z, 2012.
Zhang, H., Zhang, Z., Cui, T., Lin, Y. H., Bhathela, N. A., Ortega, J., Worton, D. R., Goldstein, A. H., Guenther, A., Jimenez, J. L., Gold, A., and Surratt, J. D.: Secondary organic aerosol formation via 2-methyl-3-buten-2-ol photooxidation: evidence of acid-catalyzed reactive uptake of epoxides, Environ. Sci. Technol. Lett., 1, 242-247, https://doi.org/10.1021/ez500055f, 2014.

Zheng, G., Su, H., Wang, S., Andreae, M. O., Pöschl, U., and Cheng, Y.: Multiphase buffer theory explains contrasts in atmospheric aerosol acidity, Science, 369, 1374-1377, https://doi.org/10.1126/science.aba3719, 2020.

Zhu, M., Jiang, B., Li, S., Yu, Q., Yu, X., Zhang, Y., Bi, X., Yu, J., George, C., Yu, Z., and Wang, X.: Organosulfur compounds formed from heterogeneous reaction between $\mathrm{SO}_{2}$ and particulate-bound unsaturated fatty acids in ambient air, Environ. Sci. Technol. Lett., 6, 318-322, https://doi.org/10.1021/acs.estlett.9b00218, 2019. 